Atmos. Chem. Phys., 18, 11149-11169, 2018

https://doi.org/10.5194/acp-18-11149-2018

(C) Author(s) 2018. This work is distributed under

the Creative Commons Attribution 4.0 License.

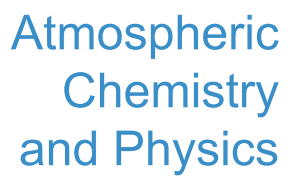

(c) (i)

\title{
Volcanic impact on the climate - the stratospheric aerosol load in the period 2006-2015
}

\author{
Johan Friberg ${ }^{1}$, Bengt G. Martinsson ${ }^{1}$, Sandra M. Andersson ${ }^{1, a}$, and Oscar S. Sandvik ${ }^{1}$ \\ ${ }^{1}$ Division of Nuclear Physics, Lund University, Lund, 22100, Sweden \\ a now at: Core service, information and statistics, Swedish Meteorological and Hydrological Institute, Norrköping, Sweden \\ Correspondence: Johan Friberg (johan.friberg@nuclear.lu.se)
}

Received: 20 December 2017 - Discussion started: 25 January 2018

Revised: 7 June 2018 - Accepted: 9 July 2018 - Published: 10 August 2018

\begin{abstract}
We present a study on the stratospheric aerosol load during 2006-2015, discuss the influence from volcanism and other sources, and reconstruct an aerosol optical depth (AOD) data set in a resolution of $1^{\circ}$ latitudinally and 8 days timewise. The purpose is to include the "entire" stratosphere, from the tropopause to the almost particle-free altitudes of the midstratosphere. A dynamic tropopause of 1.5 PVU was used, since it enclosed almost all of the volcanic signals in the CALIOP data set. The data were successfully cleaned from polar stratospheric clouds using a temperature threshold of $195 \mathrm{~K}$. Furthermore, a method was developed to correct data when the CALIOP laser beam was strongly attenuated by volcanic aerosol, preventing a negative bias in the AOD data set. Tropospheric influence, likely from upwelling dust, was found in the extratropical transition layer in spring. Eruptions of both extratropical and tropical volcanoes that injected aerosol into the stratosphere impacted the stratospheric aerosol load for up to a year if their clouds reached lower than $20 \mathrm{~km}$ altitude. Deeper-reaching tropical injections rose in the tropical pipe and impacted it for several years. Our AODs mostly compare well to other long-term studies of the stratospheric AOD. Over the years 2006-2015, volcanic eruptions increased the stratospheric AOD on average by $\sim 40 \%$. In absolute numbers the stratospheric AOD and radiative forcing amounted to 0.008 and $-0.2 \mathrm{~W} \mathrm{~m}^{-2}$, respectively.
\end{abstract}

\section{Introduction}

Aerosol particles have a large impact on the Earth's climate. Trends in the abundance of aerosol particles are an important component of the climate system, although their influence on climate is still highly uncertain (IPCC, 2014). For example, volcanic eruptions inject particles and the sulfateforming precursor gas sulfur dioxide $\left(\mathrm{SO}_{2}\right)$ into the stratosphere, where submicron particles may remain for up to several years. There, the aerosol particles scatter and absorb solar radiation, hindering it from heating the surface of the Earth. The eruption of Mt Pinatubo in 1991 resulted in a global cooling in excess of $0.5^{\circ} \mathrm{C}$ in the following years ( $\mathrm{Mc}-$ Cormick et al., 1995).

In recent years much attention has been drawn to a discrepancy between the Earth system models' (CMIP5) projections of temperatures to those of an observed slow-down in the warming trend in the beginning of this century (Fyfe et al., 2013, 2016; Rajaratnam et al., 2015; Trenberth, 2015; Xie et al., 2016; Yan et al., 2016), often called the hiatus. Part of the discrepancy was caused by bias in the temperature data (Karl et al., 2015). Likely reasons behind the remaining discrepancy are fluctuations in oceanic heat sequestration, solar blocking by volcanic aerosol in the stratosphere, and solar forcing not captured by the state-of-the-art models (Andersson et al., 2015; Medhaug et al., 2017; Meehl and Teng, 2014; Myhre et al., 2013; Santer et al., 2014; Solomon et al., 2011).

In the past decade several volcanic eruptions perturbed the stratospheric aerosol load, causing periods of increased stratospheric aerosol optical depth (AOD) that have been observed via remote sensing from satellites as well as groundbased (Khaykin et al., 2017; Sakai et al., 2016; Vernier et al., 
2011; Zuev et al., 2017), and in situ observations (Martinsson et al., 2017).

In the tropics, upwelling tropospheric air enters the stratosphere, bringing aerosol particles and precursor gases including $\mathrm{SO}_{2}$ and carbonyl sulfide (OCS), contributing to the background stratospheric aerosol. Which of these components that dominates as source is still a topic of debate (Brühl et al., 2012; Sheng et al., 2015). While the water-soluble $\mathrm{SO}_{2}$ may be scavenged by cloud processes in convective transport, a large fraction of the OCS is transported to the stratosphere where it is oxidized by UV radiation at $\sim 25 \mathrm{~km}$ altitude and contributes to the Junge layer (Crutzen, 1976). A recent study by Rollins et al. (2017) indicates that $\mathrm{SO}_{2}$ concentrations in the tropical upper troposphere (UT) are too low for general tropical $\mathrm{SO}_{2}$ upwelling to be a significant source of the stratospheric background aerosol.

Sulfate is the dominating constituent in the stratospheric background as well as in the volcanic aerosol (Deshler, 2008). In addition, organics (Friberg et al., 2014; Murphy et al., 2014), meteoritic matter, soil dust, and volcanic ash can be found in stratospheric aerosol particles. The ash component decreases rapidly after a volcanic eruption as the large ash particles are gravitationally separated from the sulfateforming volcanic $\mathrm{SO}_{2}$ layers and subside out of the stratosphere. Therefore it generally constitutes only a small fraction of the stratospheric aerosol.

Sandwiched between the tropopause and the overlying $380 \mathrm{~K}$ isentrope, the lowermost stratosphere (LMS) constitutes the lowest part of the stratosphere. It is connected with the troposphere through isentropic surfaces crossing the tropopause, where significant bidirectional transport of air takes place (Holton et al., 1995). Local air exchange occurs in a region extending a couple of kilometers above the tropopause, termed the extratropical transition layer (ExTL; Hoor et al., 2002). The ExTL is characterized by steep gradients in chemical species that have different concentration levels in the troposphere and stratosphere (Gettelman et al., 2011).

The Brewer-Dobson circulation transports air meridionally from the tropical stratosphere, in an overturning circulation (Gettelman et al., 1997). Most of the air is transported in a low-altitude, or shallow, branch that spans an isentropic range of 380 to $\sim 450-470 \mathrm{~K}$ (Fueglistaler et al., 2009; Lin and $\mathrm{Fu}, 2013)$. A portion of the air ascends in the so-called tropical pipe. This high-altitude, or deep, branch extends to the stratopause ( $\sim 50 \mathrm{~km}$ altitude) and transports the air slowly, resulting in residence times of several years (Bönisch et al., 2009). Air is then subsiding through the midlatitude and polar stratosphere, bringing aerosol particles down to the LMS from higher stratospheric altitudes that eventually end up in the troposphere, where they are rapidly scavenged by cloud processes.

The CALIOP (Cloud-Aerosol Lidar with Orthogonal Polarization) instrument uses a lidar to retrieve observations of the backscattering from aerosol particles and clouds at high vertical resolution (Winker et al., 2007). Vernier et al. (2009) developed a method of filtering out clouds, to study the backscattering from aerosol particles above $15 \mathrm{~km}$ altitude. The stratospheric AOD values have been computed from the lidar backscattering from particles by assumptions on particle size distribution and composition (Jäger and Deshler, 2002, 2003). Solomon et al. (2011) estimated the radiative forcing induced by the injection of volcanic aerosol above $15 \mathrm{~km}$ altitude during year 2000-2010 to be on average $\sim-0.1 \mathrm{~W} \mathrm{~m}^{-2}$. Their approach excluded the lowerlying LMS, which contains approximately $40 \%$ of the stratospheric mass. Including the LMS, Ridley et al. (2014) and Andersson et al. (2015) revealed that the LMS contains a significant fraction of the stratospheric aerosol, which influence on the AOD had been neglected in previous studies. Hence, for estimation of the full climate impact of volcanism one needs to consider the whole stratospheric column.

In this paper we present the volcanic influence on the "entire" stratospheric AOD (from the tropopause to $35 \mathrm{~km}$ altitude) over time and space, starting with studies on the transport of volcanic aerosol within the stratosphere. New techniques of handling the CALIOP data will be presented and discussed: one being the removal of signals from polar stratospheric clouds (PSCs) and the other a means of correcting data in periods when the lidar signal becomes attenuated by dense aerosol layers. Finally, the regional and global AODs are presented for the entire stratosphere in relation to transport patterns. As a means of representing the residence time of the aerosol from eruptions at several latitudes, reaching various altitudes, the AOD is presented for three stratospheric layers: the LMS, the potential temperature range of 380 to $470 \mathrm{~K}$, and altitudes above the $470 \mathrm{~K}$ isentrope.

\section{The CALIOP data}

This study of the stratospheric aerosol in the time period 2006-2015 is based on measurements with the CALIOP instrument aboard the satellite CALIPSO (Cloud-Aerosol Lidar and Infrared Pathfinder Satellite Observation) in a joint mission of NASA and the French space agency, CNES. The almost nadir-viewing $\left(3^{\circ}\right)$ CALIOP is a two-wavelength lidar utilizing three receiver channels (Winker et al., 2007, 2009). One channel measures backscatter intensity at $1064 \mathrm{~nm}$ and two channels measure orthogonally polarized backscatter intensity at $532 \mathrm{~nm}$. The measurements result in highresolution vertical profiles of aerosols and clouds: in the altitude ranges 8.2-20.2, 20.2-30.1, and 30.1-40 km, with respective vertical resolutions of 60,180 , and $300 \mathrm{~m}$. During 1 day, CALIPSO performs approximately 15 orbits between $82^{\circ} \mathrm{S}$ and $82^{\circ} \mathrm{N}$ with a repeat cycle of 16 days (Winker et al., 2010).

This work is based on the Level 1B (version 4-10) nighttime products of the $532 \mathrm{~nm}$ perpendicular and parallel polarized channels. Together, the two channels provide the 

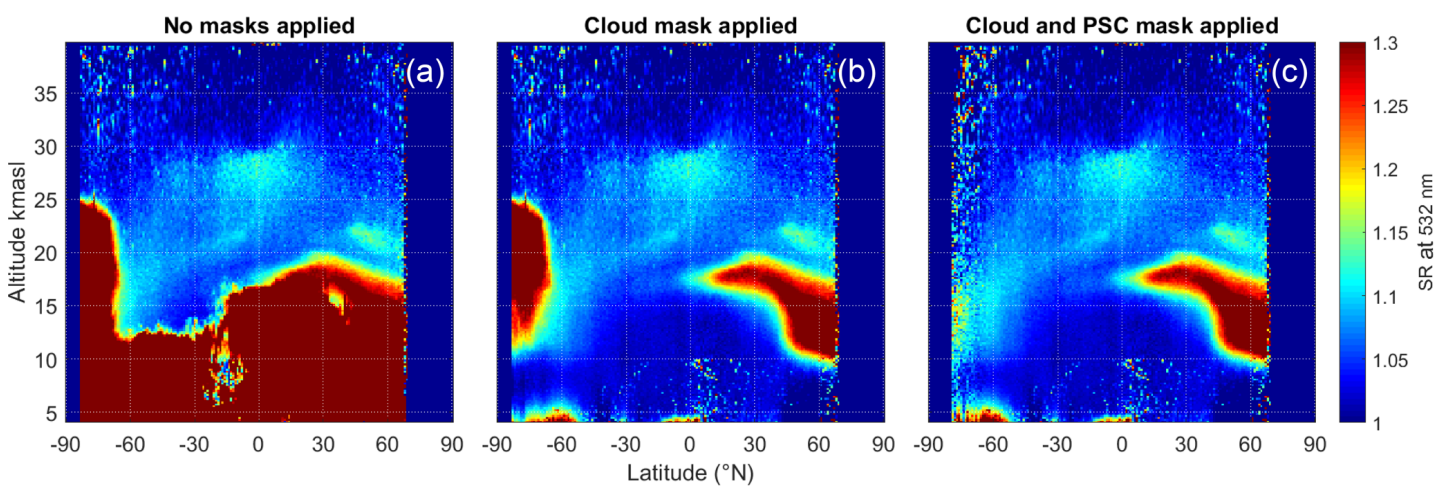

Figure 1. Illustration of the removal of cloud signals from the CALIOP data: (a) the original data and (b, c) removal of signals from ice clouds and polar stratospheric clouds, respectively. Data averaged over August 2009 were used in this example. The strong aerosol signal in the Northern Hemisphere comes from aerosol connected to the Sarychev eruption.

backscatter intensity. Their ratio, called polarization ratio, is used to infer the shape of the scattering objects. In the present study each swath measured by CALIOP was averaged over $1^{\circ}$ in latitude and averaged or interpolated to $180 \mathrm{~m}$ in altitude. Polarization ratios were used to identify pixels containing clouds. From that a mask was formed for removal of pixels containing signals from clouds, using a $5 \%$ threshold in the polarization ratio (Vernier et al., 2009). The mask was expanded to remove weak signals from the edges of clouds, and data below thick clouds were excluded (Andersson et al., 2015); compare Fig. 1b with Fig. 1a for an example.

The measured backscattering intensity is the sum of the scattering from aerosol particles and air molecules. To separate these two components, the molecular scattering of the air was modeled based on ozone number density, atmospheric temperature, and pressure from the Global Modeling and Assimilation Office (GMAO). In this study we use the ratio of the total scattering $(\beta)$ to the modeled molecular scattering $\left(\beta_{\mathrm{m}}\right)$, the so-called scattering ratio (SR), and the difference between them, the aerosol scattering (AS):

$$
\begin{aligned}
& \mathrm{SR}=\frac{\beta}{\beta_{\mathrm{m}}}, \\
& \mathrm{AS}=\beta-\beta_{\mathrm{m}}=(\mathrm{SR}-1) \cdot \beta_{\mathrm{m}},
\end{aligned}
$$

The SR is an optical equivalent to mixing ratio and the AS to aerosol concentration.

The measured backscattering intensity is an "attenuated backscattering" $\left(\beta^{\prime}\right)$, due to light extinction of the laser pulses caused by molecules and particles. The attenuation that the laser pulses experience while passing through the atmosphere is estimated using the so-called two-way transmission parameter $\left(T^{2}\right)$, which is the product of the two-way transmissions by the two components (molecules and particles). The molecular part is estimated from modeling data of the molecular background (Hostetler et al., 2006; Winker et al., 2009), while the attenuation from particles is generally considered negligible (e.g., Khaykin et al., 2017; Vernier et al., 2009). We will discuss this in Sect. 5, along with a method we developed to correct for the increased attenuation occurring during periods when volcanism increased the stratospheric aerosol load. The improved calibration in the version 4 (V4) data has reduced the bias of CALIOP, and by comparison to airborne lidar (the HSRL: high spectral resolution lidar) Kar et al. (2018) estimate the bias to be $1.6 \pm 2.4 \%$. Up to $60 \%$ of the mean bias (1.6\%) may have come from undetected clouds and aerosols, suggesting it to be even lower. We use the latest version of the CALIOP V4 data (V4-10), and therefore expect potential bias in $\beta^{\prime}$ to have low impact on our data analysis.

\section{Computing the stratospheric AOD}

The AOD as a function of latitude was obtained by integrating the AS in the vertical direction and multiplying it with the so-called lidar ratio, i.e., the extinction-to-backscattering ratio. The lidar ratio has been estimated in many studies and is usually reported to span a range of values from $\sim 40$ to $\sim 70$ sr for stratospheric aerosol (Jäger et al., 1995; Kremser et al., 2016; Prata et al., 2017 and references therein). In a thorough study Jäger and Deshler (2003) reported a value of $50 \mathrm{sr}$ for background stratospheric aerosol concentration and size distribution occurring at the end of the 1990s. This value is commonly used for CALIOP (e.g., Hostetler et al., 2006; Khaykin et al., 2017; Solomon et al., 2011) and with that value Khaykin et al. (2017) found good agreement between CALIOP, other satellite instruments, and ground-based lidar. In a recent long-term study, Thomason et al. (2018) found a CALIOP lidar ratio of $53 \mathrm{sr}$, by comparing to data from the OSIRIS instrument. Prata et al. (2017) found that lidar ratios of volcanic aerosol after the eruptions of Kasatochi (2008), Sarychev (2009) and Puyehue-Cordón Caulle (2011), where $\sim 20-30 \%$ higher but not statistically differing from the values reported by Jäger and Deshler (2003) and Thomason et al. (2018). They used data from detected layers of relatively 
fresh volcanic aerosol, whereas we use zonal means where the volcanic and background aerosol are averaged together.

The aerosol particle size distribution is needed to obtain the AOD from the CALIOP lidar measurements. It is well established that large volcanic eruptions like that of $\mathrm{Mt}$ Pinatubo in 1991 cause a shift towards larger particle sizes in the stratosphere (Deshler, 2008), resulting in a variable relation between lidar backscatter and extinction (Jäger and Deshler, 2003). Measurements in the LMS show that volcanic eruptions of Grimsvötn and Nabro in 2011 had only a minor influence on the particle size distribution (Martinsson et al., 2014), and they were similar to size distributions obtained in periods of small volcanic impact (Jäger and Deshler, 2002). We will therefore use the more conservative lidar ratio of $50 \mathrm{sr}$, corresponding to the background stratospheric aerosol (Jäger and Deshler, 2003), which is also close to the value of $53 \mathrm{sr}$ retrieved by Thomason et al. (2018).

Existing stratospheric AOD data sets exclude the LMS. They are based on measurements where the AOD was integrated with the lower altitude limit being either the $380 \mathrm{~K}$ isentrope (Bourassa et al., 2012; Sato et al., 1993) or $15 \mathrm{~km}$ altitude (Solomon et al., 2011; Vernier et al., 2011). A first AOD estimation based on high-resolution measurements that included the LMS were presented by Andersson et al. (2015). As the lower altitude limit of the AOD integration they used the tropopause supplied with the CALIOP data set, a thermal tropopause (Pan and Munchak, 2011) based on GEOS5 (Goddard Earth Observing System Model Version 5) data. The thermal tropopause according to the WMO definition on average resides more than $1 \mathrm{~km}$ above the dynamic tropopause of 1.5 PVU in the extratropics (Wilcox et al., 2012).

In the present study we use a dynamic tropopause as it captures the chemistry better than the thermal one does. This is reflected in that part of the volcanic aerosol in the present study residing below the thermal tropopause. The location of the dynamic tropopause was computed from potential vorticity (PV) values obtained from ERA-Interim reanalysis data provided by the ECMWF (European Center for Medium Ranged Weather Forecasts), and averaged to the same resolution as was the CALIOP data $\left(1^{\circ}\right.$ latitudinally, $180 \mathrm{~m}$ vertically). Using a lower tropopause will of course increase the stratospheric AOD and the duration of effects on stratospheric AOD from volcanic eruptions. It will thereby provide a better estimate of the total stratospheric AOD. However, lowering the tropopause leads to more influence from the ExTL (Hoor et al., 2004), thus increasing the influence from tropospheric aerosol on the estimate of the stratospheric AOD. The location of the dynamic tropopause will be discussed more in Sect. 6.2.

\section{Handling PSCs}

The occasional presence of PSCs results in strong backscattering signals in the winter polar stratosphere that can cause bias to the stratospheric AOD. This is especially problematic in the Southern Hemisphere where the PSCs occur at latitudes from $60^{\circ} \mathrm{S}$. This is illustrated in Fig. 1a as the high SR extending up to $25 \mathrm{~km}$ altitude in the Antarctic region. For investigation of the volcanic influence on the stratospheric aerosol, the influence from PSCs needs to be negligible, requiring a means of excluding data affected by these clouds. Andersson et al. (2015) solved this problem by manually omitting periods with PSCs. In the present study, we present a general approach to exclude the PSCs from the aerosol data.

Since PSC formation requires temperatures below $195 \mathrm{~K}$, that temperature was used as a minimum threshold for a PSC mask applied to the polar regions, as a means of minimizing the bias from PSCs. Furthermore, data below the clouds were removed to avoid bias from the strongly attenuated signals below the optically dense PSCs. This automated approach resulted in an almost complete removal of PSC signals, as illustrated by comparing Fig. 1b and c, while keeping almost all of the data. Weak PSC signals remain, but its influence becomes negligible when averaged globally or hemispherically since the Antarctic region (60-90 $\mathrm{S}$ ) constitutes only $6 \%$ of the Earth's surface area.

\section{Correcting for errors caused by particle extinction}

\subsection{Attenuation of the laser}

Passing through the atmosphere, the laser beam is attenuated by scattering and absorption from aerosol particles, molecules, and $\mathrm{O}_{3}$. Thus, the CALIOP instrument retrieves an "attenuated backscattering" from laser pulses. Computing the true backscattering requires information on the extinction through the overlying atmosphere. The attenuation is accounted for by the two-way transmission $\left(T^{2}\right)$, where an expression for the corrected backscattering becomes

$\beta=\frac{\beta^{\prime}}{T^{2}}$

where $\beta^{\prime}$ is the attenuated backscattering retrieved by CALIOP. The two-way transmission depends on two attenuating components, i.e., that of molecules $\left(T_{\mathrm{m}}^{2}\right)$ and particles $\left(T_{\mathrm{p}}^{2}\right)$ (Young et al., 2005), and can be expressed as their product:

$T^{2}=T_{\mathrm{m}}^{2} \cdot T_{\mathrm{p}}^{2}$

where the absorption from ozone molecules is here included in $T_{\mathrm{m}}^{2}$. By combining Eq. (1), (3), and (4), an expression for the SR corrected from both molecular extinction and parti- 
cles becomes

$\mathrm{SR}_{\mathrm{mpC}}=\frac{\beta^{\prime}}{T_{\mathrm{m}}^{2} \cdot T_{\mathrm{p}}^{2} \cdot \beta_{\mathrm{m}}}$.

Attenuation from molecules is computed based on modeling, but that by particles is generally not considered in studies based on CALIOP data. For example, Vernier et al. (2009) and Khaykin et al. (2017) discuss that the attenuation from particles is less than $1 \%$ at $15 \mathrm{~km}$ altitude in the absence of strong volcanic eruptions, arguing that corrections are unnecessary during these time periods. Assuming $T_{\mathrm{p}}^{2}=1$, the expression for the SR corrected from molecular extinction becomes

$\mathrm{SR}_{\mathrm{mC}}=\frac{\beta^{\prime}}{T_{\mathrm{m}}^{2} \cdot \beta_{\mathrm{m}}}$

from which the molecular-extinction-corrected $\mathrm{AS}\left(\mathrm{AS}_{\mathrm{mC}}\right)$ can be computed using Eq. (2).

Volcanic clouds may, however, result in non-negligible attenuation of the lidar signals. By neglecting the attenuation caused by particles, part of the aerosol signal will be accounted for as signal coming from molecules, because the latter signal is also attenuated by the aerosol. Unaccounted for, the attenuation by volcanic aerosol particles can result in underestimation of the full effect of the volcanic impact of the stratospheric aerosol load and the corresponding AOD. The attenuation is naturally increasing as the laser beams (and scattered light) pass through the atmosphere, causing the largest errors to occur for signals retrieved from the lower altitude side of volcanic clouds, and below them. In the present work this corresponds to the strongest attenuation being at the tropopause and in the UT.

In the present study, we first corrected the data by computing the two-way transmission caused by the attenuation from molecules (Eq. 6). This correction is sufficient in the absence of volcanic clouds, but light extinction caused by aerosol particles in dense volcanic clouds resulted in further attenuation of the CALIOP laser. This is evident in Fig. 2 (black dashed line) where apparent decreases in SR arise in the UT after the volcanic eruptions of Sarychev, Nabro, and Calbuco. The most dramatic decrease is observed for the SR data after the eruption of Calbuco in 2015, where strong attenuation resulted in unphysically low SR, i.e., below 1 .

\subsection{Estimating the two-way transmission from particle extinction}

The two-way transmission from particles can be retrieved by a complicated technique in which strongly attenuating features in the CALIOP data are first identified and then an iterative process is used as means of estimating particle extinctions in attenuating layers (Young et al., 2005). The layer detection requires the use of a threshold value for identification of attenuating features. The resulting particle extinction parameter in the CALIOP Level 2 data is compared with the AS in Fig. 3. The patterns of the Level 2 particle extinction (Fig. 3a and c) and those of the AS (Fig. 3b and d) do not match. The algorithm obviously fails to detect most of the relatively fresh volcanic clouds, and when the volcanic aerosol is mixed with the background aerosol 5 months after the eruption (Fig. 3c and d) the Level 2 procedure does not detect any attenuating aerosol. In Fig. $2 \mathrm{~b}$ it is clear that the SR in the UT still is strangely lowered 5 months after the Calbuco eruption. We therefore developed a means of correcting for the attenuation caused by volcanic aerosol particles, where the particle-related two-way transmission $\left(T_{\mathrm{p}}^{2}\right)$ is calculated and applied to the $\mathrm{SR}_{\mathrm{mC}}$ data. This procedure follows below.

The apparent decrease in the UT SR (Fig. 2) following the largest eruptions of the time period studied indicates attenuation of the laser signal induced by particles. By assuming that the UT conditions remain approximately unchanged after volcanic eruptions the degree of attenuation in a given volcanically perturbed time and place can be estimated by comparison with the signals in the years without strong volcanic influence. However, a volcanically perturbed stratosphere results in a small elevation of the UT aerosol concentration. That effect can be assumed to be small for most of the eruptions of this study, but the lower cloud of Kasatochi had a direct impact on the UT aerosol load (Andersson et al., 2015). In Sect. 5.2 we present a method to handle that eruption separately. By assuming the UT conditions to remain approximately unchanged after all but the Kasatochi eruption, we can estimate the two-way transmission from particles at the altitude of the tropopause:

$$
\begin{gathered}
\left\langle\mathrm{SR}_{\mathrm{ut}}\right\rangle_{\mathrm{v}}=\left\langle\mathrm{SR}_{\mathrm{ut}}\right\rangle_{\mathrm{bg}} \Rightarrow \frac{\left\langle\mathrm{SR}_{\mathrm{mC}, \mathrm{ut}}\right\rangle_{\mathrm{v}}}{\left\langle T_{\mathrm{p}, \mathrm{ut}}^{2}\right\rangle_{\mathrm{v}}}=\frac{\left\langle\mathrm{SR}_{\mathrm{mC}, \mathrm{ut}}\right\rangle_{\mathrm{bg}}}{\left\langle T_{\mathrm{p}, \mathrm{ut}}^{2}\right\rangle_{\mathrm{bg}}} \\
\Rightarrow \frac{\left\langle T_{\mathrm{p}, \mathrm{tp}}^{2}\right\rangle_{\mathrm{v}}}{\left\langle T_{\mathrm{p}, \mathrm{tp}}^{2}\right\rangle_{\mathrm{bg}}}=\frac{\left\langle\mathrm{SR}_{\mathrm{mC}, \mathrm{ut}}\right\rangle_{\mathrm{v}}}{\left\langle\mathrm{SR}_{\mathrm{mC}, \mathrm{ut}}\right\rangle_{\mathrm{bg}}},
\end{gathered}
$$

where $T_{\mathrm{p}, \mathrm{tp}}^{2}$ is the two-way transmission at the tropopause, and the indexes $\mathrm{v}$ and $\mathrm{bg}$ represent volcanic and background conditions. Furthermore, we assume that $\left\langle T_{\mathrm{p}, \mathrm{tp}}^{2}\right\rangle_{\mathrm{bg}}=1$ since the particle extinction is small in background conditions, and we end up with

$\left\langle T_{\mathrm{p}, \mathrm{tp}}^{2}\right\rangle_{\mathrm{v}}=\frac{\left\langle\mathrm{SR}_{\mathrm{mC}, \mathrm{ut}}\right\rangle_{\mathrm{v}}}{\left\langle\mathrm{SR}_{\mathrm{mC}, \mathrm{ut}}\right\rangle_{\mathrm{bg}}}$.

$T^{2}$ values can theoretically be in the range of 0 to 1 . In this work $\left\langle T_{\mathrm{p}, \mathrm{tp}}^{2}\right\rangle_{\mathrm{v}}$ are distributed from 0.95 to 1 , with the majority of values being $>0.97$. Thus, the decreases in SR under volcanic clouds are mostly on the order of $2-5 \%$, which may appear to be negligibly low. For example, Fig. 2a shows typical decreases in SR to be on the order of 0.025 in absolute terms, from for example $\left\langle\mathrm{SR}_{\mathrm{mC}, \text { ut }}\right\rangle_{\mathrm{bg}}$ of 1.050 to $\left\langle\mathrm{SR}_{\mathrm{mC}, \text { ut }}\right\rangle_{\mathrm{v}}$ of 1.025. Using Eq. (7) these values correspond to a $\left\langle T_{\mathrm{p}, \mathrm{tp}}^{2}\right\rangle_{\mathrm{v}}$ of 0.976. However, transferred to the AS and AOD these deviations become relevant. Using Eq. (2), and assuming $\beta_{\mathrm{m}}$ to 

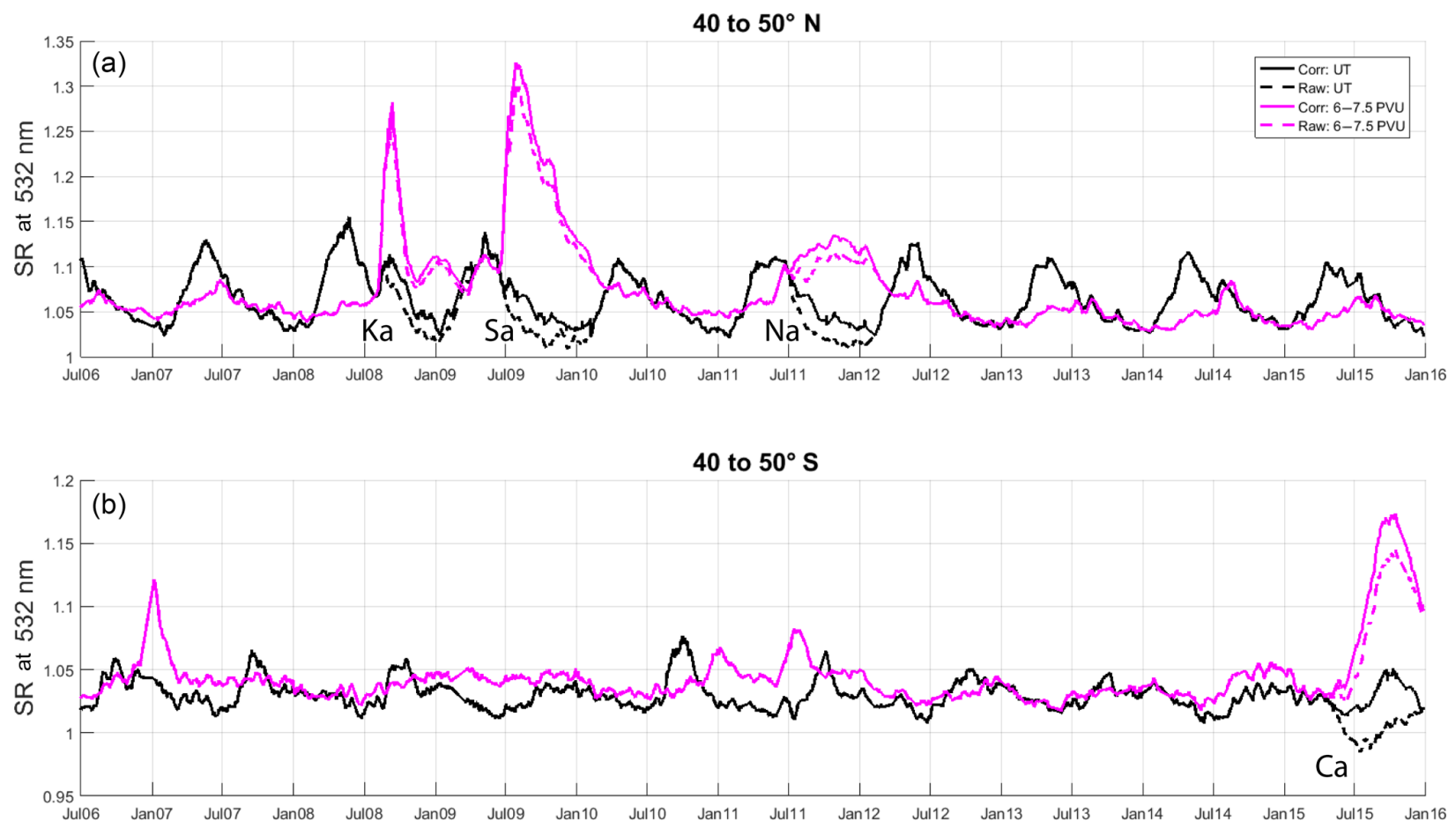

Figure 2. Examples illustrating the effects from corrections made to compensate for the laser attenuation caused by aerosol particles. The scattering ratios (SR) were averaged over the latitude intervals (a) $40-50^{\circ} \mathrm{N}$ and (b) $40-50^{\circ} \mathrm{S}$ for the UT (black; 250-1000 $\mathrm{m}$ below the tropopause) and the PV layer of 6-7.5 PVU (magenta). Volcanic eruptions are indicated by their abbreviations. Both layers are on average approximately $750 \mathrm{~m}$ thick). Corrected (uncorrected) data are marked as full (dashed) lines.
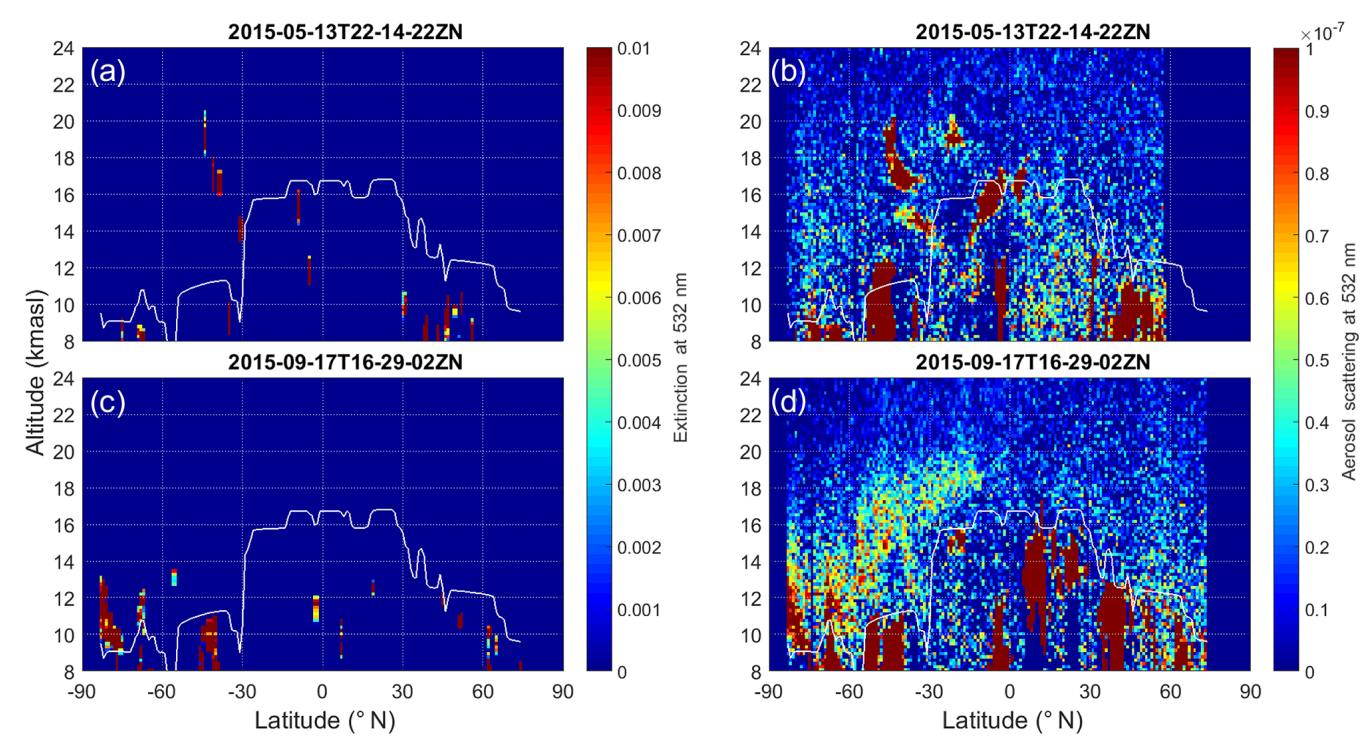

Figure 3. Comparisons of the particle extinction parameter from the level 2 data v4-10 (a, c) and the aerosol scattering (b, d) taken after the Calbuco eruption. The upper figures were taken 3 weeks after the eruption (on 13 May 2015), and the lower almost 4 months after the eruption (on 17 September 2015). Data in b and d were based on the attenuated backscattering at $532 \mathrm{~nm}$ in the level $1 \mathrm{v} 4-10$ data, and modeling of the molecular scattering. The white lines mark the thermal tropopause. 
be equal during volcanic periods and background, we end up with

$$
\frac{\left\langle\mathrm{AS}_{\mathrm{mC}, \mathrm{ut}}\right\rangle_{\mathrm{v}}}{\left\langle\mathrm{AS} \mathrm{S}_{\mathrm{mC}, \mathrm{ut}}\right\rangle_{\mathrm{bg}}}=\frac{\left\langle\mathrm{SR}_{\mathrm{mC}, \mathrm{ut}}\right\rangle_{\mathrm{v}}-1}{\left\langle\mathrm{SR}_{\mathrm{mC}, \mathrm{ut}}\right\rangle_{\mathrm{bg}}-1}=\frac{1.025-1}{1.050-1}=0.50
$$

the $\left\langle\mathrm{AS}_{\mathrm{mC} \text {,ut }}\right\rangle_{\mathrm{v}}$ and $\left\langle\mathrm{AS}_{\mathrm{mC} \text {, ut }}\right\rangle_{\mathrm{bg}}$ being the AS in the UT during volcanic and background conditions. Thus, if the attenuation by particles is unaccounted for, the AOD of the UT gets underestimated by as much as $50 \%$ in the current example, since we retrieve the AOD linearly from the AS. A small effect on the SR is transformed into a large effect on the AS and AOD because before the correction half of the aerosol signal was accounted as signal from molecules in the example above. This simple example illustrates that apparent tiny decreases in the $T^{2}$ may result in large underestimations in the computed AOD of low altitude layers, i.e., the LMS and especially the ExTL and UT. Once computed, the $\left\langle T_{\mathrm{p}, \mathrm{tp}}^{2}\right\rangle_{\mathrm{v}}$ are combined with the column-integrated $\mathrm{AS}_{\mathrm{mC}}$ data to compute two-way transmission matrices for the whole stratospheric column $\left(T_{\mathrm{p}}^{2}\right)$.

To compute $T_{\mathrm{p}}^{2}$ values for the whole stratospheric column, the integrated column of stratospheric $\mathrm{AS}_{\mathrm{mC}}$ values are used as a means of normalizing the $T_{\mathrm{p}}^{2}$ values from the "top of the atmosphere" (TOA), here $35 \mathrm{~km}$ altitude, down to the tropopause. In this procedure the uppermost altitude bin gets a $T_{\mathrm{p}}^{2}$ value of 1 , and altitude bins below get lower $T_{\mathrm{p}}^{2}$ values, down to the tropopause where the $T_{\mathrm{p}, \mathrm{tp}}^{2}$ is computed from Eq. (7). We start by using the fraction that becomes extinct by particles:

$\mathrm{Ext}_{\mathrm{p}}=1-T_{\mathrm{p}}$

and formulate an expression for estimating the fraction extinct in a single altitude bin $(a)$,

$$
\operatorname{Ext}_{\mathrm{p}, \mathrm{a}}=\frac{\mathrm{AS}_{\mathrm{mC}, \mathrm{a}}}{\sum_{\mathrm{TP}}^{\mathrm{TOA}} \mathrm{AS}_{\mathrm{mC}}(z)} \cdot \mathrm{Ext}_{\mathrm{p}, \mathrm{tp}}
$$

where $\mathrm{Ext}_{\mathrm{p}, \mathrm{tp}}$ is the extinct fraction at the tropopause (1 $\left.T_{\mathrm{p}, \mathrm{tp}}\right), \mathrm{AS}_{\mathrm{mC}, \mathrm{a}}$ is the molecular corrected AS in altitude bin $a$, and the denominator holds the integrated backscattering for the total stratospheric column where $z$ is the altitude bin. The transmission through the column can be computed by multiplying the transmission through each layer. Such an approach may result in instabilities when the $\mathrm{AS}_{\mathrm{mC}}$ values become close to zero or negative, as was the case after the eruption of Calbuco, i.e., the $\mathrm{SR}_{\mathrm{mC}}<1$ in Fig. 2 b corresponds to negative $\mathrm{AS}_{\mathrm{mC}}$. By instead assuming linearity we can compute the extinction at each altitude simply by summing the extinction in each overlying layer. Combined with Eq. (8), this procedure yields the following expression for the altitudedependent two-way transmission from particles:
$T_{\mathrm{p}}^{2}(z)=\left\{1-\frac{\sum_{z+1}^{\mathrm{TOA}} \mathrm{AS}_{\mathrm{mC}}(z)}{\sum_{\mathrm{TP}}^{\mathrm{TOA}} \mathrm{AS}_{\mathrm{mC}}(z)}\left(1-T_{\mathrm{p}, \mathrm{pp}}\right)\right\}^{2}$,

where $z$ is the altitude bin, and the TOA is at $35 \mathrm{~km}$ altitude. This linear method produces $T_{\mathrm{p}}^{2}$ values that in the current study deviate by $\ll 1 \%$ from those computed by the multiplicative method, and the resulting AOD values deviate by $<1 \%$. However, the deviations grow with the size of the particle extinction values and may become more relevant for eruptions of the size of the 1991 Pinatubo eruption.

\section{The Kasatochi eruption}

Since Kasatochi's lower cloud increased the UT aerosol load the $\left\langle T_{\mathrm{p}, \mathrm{tp}}^{2}\right\rangle_{\mathrm{v}}$ could not be retrieved directly using Eq. (7) for that eruption. Instead we made use of the similar extratropical eruption of Sarychev. For Sarychev we found the extinct fraction $\left(1-\left\langle T_{\mathrm{p}, \mathrm{tp}}\right\rangle_{\mathrm{Sar}}\right)$ to be related to the amount of aerosol in the column, i.e., the column-integrated AS ( $\left.\sum_{\mathrm{TP}}^{\mathrm{TOA}} \mathrm{AS}_{\mathrm{Sar}}\right)$. The $\left\langle T_{\mathrm{p}, \mathrm{tp}}^{2}\right\rangle_{\mathrm{v}}$ after Kasatochi was estimated indirectly from that relation:

$$
\frac{\sum_{\mathrm{TP}}^{\mathrm{TOA}} \mathrm{AS}_{\mathrm{Kas}}}{1-\left\langle T_{\mathrm{p}, \mathrm{tp}}\right\rangle_{\mathrm{Kas}}}=\frac{\sum_{\mathrm{TP}}^{\mathrm{TOA}} \mathrm{AS}_{\mathrm{Sar}}}{1-\left\langle T_{\mathrm{p}, \mathrm{tp}}\right\rangle_{\mathrm{Sar}}},
$$

where the indexes indicate the respective volcano. Combined with Eq. (8) and rearranging yields the expression for estimating the UT-particle-related two-way transmission after the Kasatochi eruption:

$\left\langle T_{\mathrm{p}, \mathrm{tp}}^{2}\right\rangle_{\mathrm{Kas}}=\left\{1-\left(\frac{\sum_{\mathrm{TP}}^{\mathrm{TOA}} \mathrm{AS}_{\mathrm{Kas}}}{\sum_{\mathrm{TP}}^{\mathrm{TOA}} \mathrm{AS}_{\mathrm{Sar}}}\right) \cdot\left\langle T_{\mathrm{p}, \mathrm{tp}}\right\rangle_{\mathrm{Sar}}\right\}^{2}$.

\subsection{Correcting the data}

Once the $T_{\mathrm{p}}^{2}$ is known, the scattering ratios can be corrected in regard to the attenuation by particles by combining Eqs. (5) and (6):

$\mathrm{SR}_{\mathrm{mpC}}=\frac{\beta^{\prime}}{T_{\mathrm{m}}^{2} \cdot T_{\mathrm{p}}^{2} \cdot \beta_{\mathrm{m}}}=\frac{\mathrm{SR}_{\mathrm{mC}}}{T_{\mathrm{p}}^{2}}$

and the corresponding aerosol scattering $\left(\mathrm{AS}_{\mathrm{mpC}}\right)$ can be computed from insertion into Eq. (2). By this, our method introduces a simple means of correcting the data to account for particle attenuation. 
To study the sensitivity of the method, an iterative process was performed where the $\mathrm{AS}_{\mathrm{mpC}}$ data were used to compute new $T_{\mathrm{p}}^{2}$ values. We found only negligible changes in the $\mathrm{SR}_{\mathrm{mpC}}$ and $\mathrm{AS}_{\mathrm{mpC}}$ after these iterations. Thus, the developed procedure was found to be a robust method for correcting stratospheric CALIOP data for the attenuation caused by particle extinction.

Correcting the CALIOP data following volcanic eruptions, according to the equations above, significantly changes the $\mathrm{SR}$, as shown in Fig. 2 (dashed vs. full lines). The global mean stratospheric AOD in the first 8 months after eruptions increased by $4 \%$ (Kasatochi), $6 \%$ (Sarychev), $6 \%$ (Nabro), and $7 \%$ (Calbuco; Fig. 2b). These numbers are the result of relatively small volcanic elevations in the stratospheric aerosol load. The influence of particle extinction naturally grows with the strength in elevation of the aerosol concentrations. Thus, eruptions of the size of the 1991 eruption of Mt Pinatubo, which was more than a magnitude larger than the eruptions of this study, would result in a strong need to correct the data for the particle extinction.

\section{Results}

Large quantities of background sulfuric acid aerosol are produced deep into the stratosphere from OCS that is transported from the tropical troposphere in the Brewer-Dobson circulation (Crutzen, 1976) together with particles, $\mathrm{SO}_{2}$, and other particle precursors from natural and anthropogenic sources. To this rather stable stratospheric background, special events inject large amounts of particles and precursor gases into the stratosphere, causing large variability in the stratospheric aerosol load. The most common cause of this variability is explosive volcanic eruptions (Robock, 2000), but large fires can occasionally influence the stratospheric aerosol (Fromm et al., 2010). For the time period studied here, mid-2006 to 2015, several volcanic eruptions and two large fires had such potential. Table 1 lists these events starting more than a year before mid-2006 to account for the long residence time of volcanic aerosol going deep into the stratosphere; e.g., the aerosol load following the Mt Pinatubo eruption in 1991 declined over several years (McCormick et al., 1995).

\subsection{The volcanic impact on the $S R$ and AS}

The stratospheric aerosol load varied substantially during the period studied, as indicated in Fig. 4, where the SR is illustrated in relation to latitude and altitude averaged for the months January, April, July, and October over the years 2006-2015. Already in the first month, July 2006, a feature is seen in the tropics at $19 \mathrm{~km}$ altitude. This was caused by the eruption of the Soufrière Hills volcano in 20 May 2006 (Vernier et al., 2009), approximately 1 month before the start of measurements from CALIPSO. In October of the same year a second feature appears to the south and at slightly lower altitude, as a result of the eruption of Rabaul in 7 October 2006. The next major feature appears in October 2008. Aerosol from the eruption of the extratropical volcano Kasatochi in 7 August 2008 formed two layers at different altitudes. The influence from this eruption remained in January 2009, and in April more volcanic aerosol was added close to the tropopause by the eruptions of Redoubt in March and April 2009. A feature appearing above $20 \mathrm{~km}$ altitude in the southern tropics in April has been identified as smoke from bush fires in February 2009 in Victoria, Australia (Vernier et al., 2011). In July 2009 the northern hemispheric stratosphere was perturbed again, this time by the extratropical volcano Sarychev (12 June 2009), with the SR signal still clearly visible in January 2010. In January 2011 aerosol from the eruption of the tropical volcano Merapi (5 November 2010) had affected mainly the southern hemispheric stratosphere. Three volcanic eruptions influenced the stratosphere in July 2011. The southern hemispheric Puyehue-Cordón Caulle (5 June 2011) and the northern hemispheric Grimsvötn (21 May 2011) affected the respective LMSs, and aerosol from the tropical Nabro (12 June 2011) went to the north and affected the stratosphere for approximately 1 year. After a couple of years with lower activity the tropical volcano Kelut erupted (13 February 2014), reaching above $20 \mathrm{~km}$ altitude. The majority of the SR signal was confined to the tropics, but over a year, part of the aerosol was transported to the extratropics while the remaining tropical aerosol rose to higher altitudes. Finally, the southern hemispheric extratropical volcano, Calbuco (23 April 2015), induced the highest SR that occurred in the Southern Hemisphere during 2006-2015. The effect of this eruption still remains at the end of the period.

Another interesting feature in Fig. 4 is the variability at altitudes above $30 \mathrm{~km}$, which is connected with the quasibiennial oscillation (QBO) (Vernier et al., 2011). The stratospheric temperature varies with the QBO, in the $30-50 \mathrm{hPa}$ layer by almost $10^{\circ} \mathrm{C}$, with the highest temperatures in the westerly shear (Baldwin et al., 2001). Modeling indicates that the QBO-associated temperature variability induces QBO-related altitude dependence in sulfuric acid evaporation from the aerosol (Hommel et al., 2015). Hence, at these altitudes less aerosol is present during the westerly shear.

The SR deals with properties relative to the air mass, but from a climatic point of view the AS, i.e., the absolute measure of the scattering by aerosols (Eq. 2), is of importance. Figure 5 shows the AS as a function of time and altitude in six latitude bands, each constituting $16 \%$ of the Earth's surface area. The white lines mark the mean upper and lower limits of the LMS, i.e., the $380 \mathrm{~K}$ isentrope and the tropopause.

Elevated AS is clearly observed both after the stronger and weaker volcanic eruptions, and a striking feature in Fig. 5 is the transport patterns where volcanic clouds in the tropics (extratropics) ascend (descend). Several eruptions reached above $380 \mathrm{~K}$, but it is also shown that a large portion of the aerosol was located in the LMS. Part of that aerosol came 
Table 1. Volcanic eruptions and wildfires in the 21st century that affect (or had the potential to affect) the aerosol loading of the stratosphere. NA is not available.

\begin{tabular}{|c|c|c|c|c|c|c|}
\hline Volcano & & Date & Lat. & Long. & $\mathrm{VEI}^{\mathrm{a}}$ & $\mathrm{SO}_{2}(\mathrm{Tg})$ \\
\hline Ulawun & & 29 September 2000 & $5^{\circ} \mathrm{S}$ & $151^{\circ} \mathrm{E}$ & 4 & NA \\
\hline Shiveluch & & 22 May 2001 & $57^{\circ} \mathrm{N}$ & $161^{\circ} \mathrm{E}$ & 4 & NA \\
\hline Ruang & & 25 September 2002 & $2^{\circ} \mathrm{N}$ & $125^{\circ} \mathrm{E}$ & 4 & $0.03^{\mathrm{b}}$ \\
\hline Reventador & & 3 November 2002 & $0^{\circ} \mathrm{S}$ & $78^{\circ} \mathrm{W}$ & 4 & $0.07^{b}$ \\
\hline Anatahan & & 10 May 2003 & $16^{\circ} \mathrm{N}$ & $146^{\circ} \mathrm{E}$ & 3 & $0.03^{b}$ \\
\hline Manam & & 27 January 2005 & $4^{\circ} \mathrm{S}$ & $145^{\circ} \mathrm{E}$ & 4 & $0.09^{b}$ \\
\hline Sierra Negra & & 22 October 2005 & $1^{\circ} \mathrm{S}$ & $91^{\circ} \mathrm{W}$ & 3 & NA \\
\hline Soufrière Hills & & 20 May 2006 & $17^{\circ} \mathrm{N}$ & $62^{\circ} \mathrm{W}$ & 3 & $0.2^{\mathrm{c}}$ \\
\hline Rabaul & $\mathrm{Rb}$ & 7 October 2006 & $4^{\circ} \mathrm{S}$ & $152^{\circ} \mathrm{E}$ & 4 & $0.2^{\mathrm{b}}$ \\
\hline Jebel at Tair & & 30 September 2007 & $16^{\circ} \mathrm{N}$ & $42^{\circ} \mathrm{E}$ & 3 & $0.08^{\mathrm{d}}$ \\
\hline Great Divides Fire & $\mathrm{Gd}$ & 1 December 2006 & $37^{\circ} \mathrm{S}$ & $144^{\circ} \mathrm{E}$ & - & - \\
\hline Chaitén & & 2 May 2008 & $43^{\circ} \mathrm{S}$ & $73^{\circ} \mathrm{W}$ & 4 & $0.01^{\mathrm{e}}$ \\
\hline Okmok & & 12 July 2008 & $53^{\circ} \mathrm{N}$ & $168^{\circ} \mathrm{W}$ & 4 & $0.1^{\mathrm{d}}$ \\
\hline Kasatochi & $\mathrm{Ka}$ & 7 August 2008 & $52^{\circ} \mathrm{N}$ & $176^{\circ} \mathrm{W}$ & 4 & $1.7^{\mathrm{d}}$ \\
\hline Fire in Victoria & $\mathrm{Vi}$ & 7 February 2009 & $37^{\circ} \mathrm{S}$ & $145^{\circ} \mathrm{E}$ & - & - \\
\hline Redoubt & & 23 March 2009 & $60^{\circ} \mathrm{N}$ & $153^{\circ} \mathrm{W}$ & 3 & $0.01^{\mathrm{f}}$ \\
\hline Sarychev & $\mathrm{Sa}$ & 12 June 2009 & $48^{\circ} \mathrm{N}$ & $153^{\circ} \mathrm{E}$ & 4 & $1.2^{\mathrm{g}}$ \\
\hline Eyjafjallajökull & & 14 April 2010 & $64^{\circ} \mathrm{N}$ & $20^{\circ} \mathrm{W}$ & 4 & NA \\
\hline Merapi & $\mathrm{Me}$ & 5 November 2010 & $8^{\circ} \mathrm{S}$ & $110^{\circ} \mathrm{E}$ & 4 & $0.4^{\mathrm{h}}$ \\
\hline Grimsvötn & $\mathrm{Gr}$ & 21 May 2011 & $64^{\circ} \mathrm{N}$ & $17^{\circ} \mathrm{W}$ & 4 & $0.4^{\mathrm{i}}$ \\
\hline Puyehue-Cordón Caulle & $\mathrm{Pu}$ & 6 June 2011 & $41^{\circ} \mathrm{S}$ & $72^{\circ} \mathrm{W}$ & 5 & $0.3^{\mathrm{i}}$ \\
\hline Nabro & $\mathrm{Na}$ & 12 June 2011 & $13^{\circ} \mathrm{N}$ & $42^{\circ} \mathrm{E}$ & 4 & $1.5^{\mathrm{i}}$ \\
\hline Kelut & $\mathrm{Ke}$ & 13 February 2014 & $8^{\circ} \mathrm{S}$ & $112^{\circ} \mathrm{E}$ & 4 & $0.2^{\mathrm{j}}$ \\
\hline Calbuco & $\mathrm{Ca}$ & 23 April 2015 & $41^{\circ} \mathrm{S}$ & $73^{\circ} \mathrm{W}$ & 4 & $0.3^{\mathrm{k}}$ \\
\hline
\end{tabular}

a Volcanic Explosivity Index (from Global Volcanism Program, http://www.volcano.si.edu/, last access: 14 November 2017).

b Prata and Bernardo (2007). ${ }^{c}$ Carn and Prata (2010). d Thomas et al. (2011). ${ }^{\mathrm{e}}$ Carn et al. (2009). ${ }^{\mathrm{f}}$ Lopez et al. (2013).

${ }^{\mathrm{g}}$ Haywood et al. (2010). ${ }^{\mathrm{h}}$ Surono et al. (2012). ${ }^{\mathrm{i}}$ Clarisse et al. (2012). ${ }^{\mathrm{j}}$ Li et al. (2017). ${ }^{\mathrm{k}}$ Pardini et al. (2017).

from the direct injection of volcanic clouds in the extratropics. Volcanic injections to higher altitudes eventually reach the LMS due to the latitudinal transport and subsidence in the midlatitudes within the Brewer-Dobson circulation. Furthermore, a seasonal variation is revealed in the strong signal from particles in the extratropical troposphere, with the maximum AS occurring in spring-summer. A small part of this tropospheric source extends into the ExTL. Its possible influence on the stratospheric aerosol load will be discussed in Sect. 6.3.

\subsection{Using the dynamic tropopause}

The dynamic tropopause was chosen to represent the lower boundary of the LMS as it is expected to best enclose the stratospheric air carrying volcanic aerosol. The PV of the dynamic tropopause varies between different studies (Gettelman et al., 2011) and is generally considered to lie somewhere in the range of 1.5-3.5 PVU (Hoerling et al., 1991; Hoinka, 1997; Kunz et al., 2011). The PV fields become vertical close to the equator. Therefore the $380 \mathrm{~K}$ isentrope is used as a limit of the dynamic tropopause's maximum possible altitude. Thus, the altitude of the dynamic tropopause be- comes the lowest of the $380 \mathrm{~K}$ isentrope and that of a chosen PV surface. The lowest commonly used dynamic tropopause, the 1.5 PVU surface, is on average located approximately $1.3 \mathrm{~km}$ below the thermal tropopause. Integration from this dynamic tropopause increases the total stratospheric AOD compared to when using the thermal tropopause. Here the aim is to use as low a PV level as possible for the best possible enclosure of the stratospheric volcanic aerosol. However, before deciding the tropopause level we need to consider the impact from tropospheric aerosol in the ExTL.

In Figs. 1 to 5, we assumed the 1.5 PVU level to be a good representation of the tropopause. Figure 6 illustrates a simple means of investigating the best-suited PV value of a dynamic tropopause where the SRs in approximately $0.25 \mathrm{~km}$ thick layers of the atmosphere above the 1.5 PVU level (LMS) are plotted for the midlatitudes of each hemisphere over the entire time frame of our study.

It is evident from Fig. 6 that the strong volcanic eruptions of Sarychev and Calbuco induced strong gradients in the SR throughout the ExTL, and that volcanic influence is present down to the lowest PV range, i.e., the 1.5-2 PVU. This is further corroborated by in situ particulate sulfur measurements (Martinsson et al., 2017). Unlike these eruptions, Kasatochi 


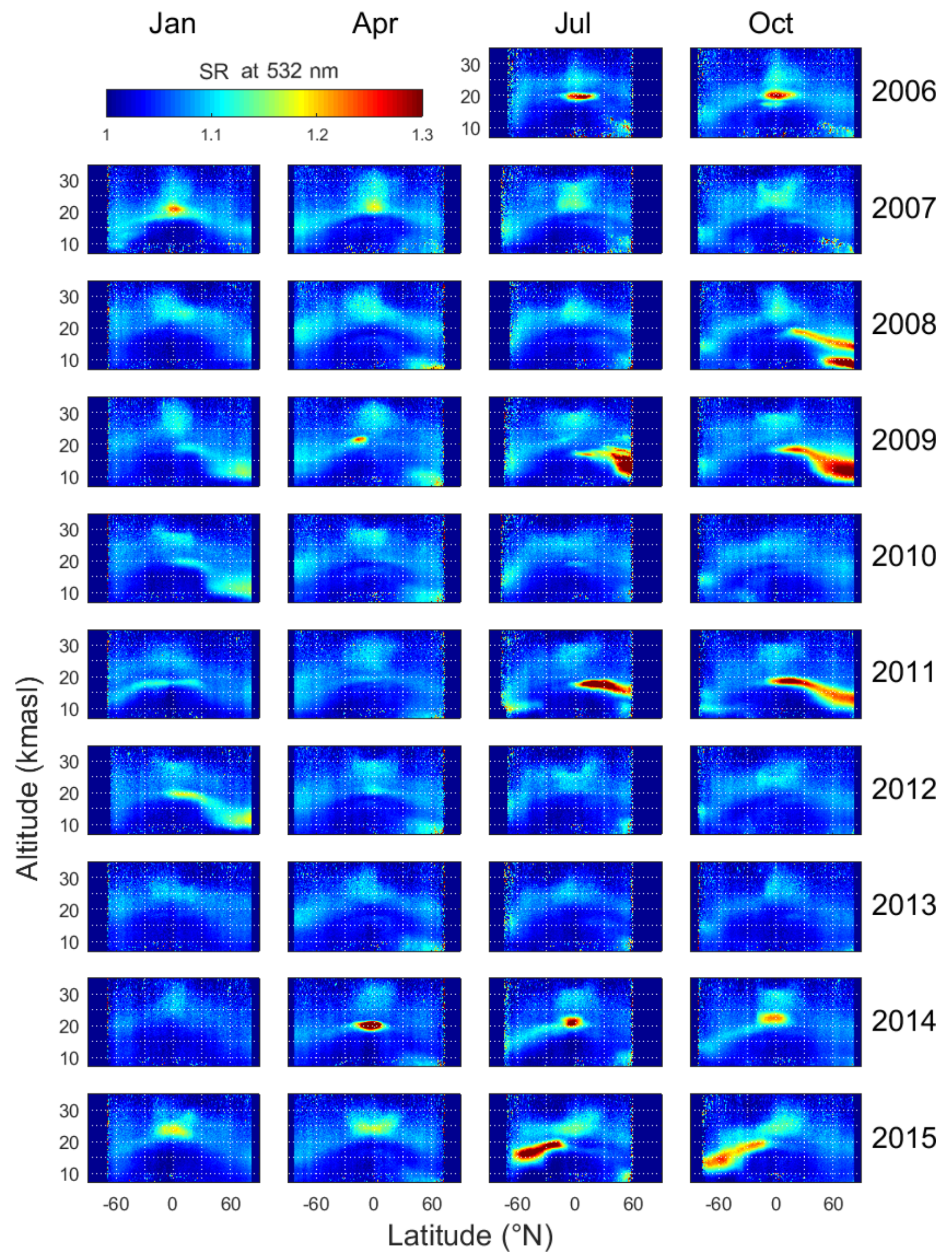

Figure 4. Monthly mean scattering ratio as a function of latitude and altitude $(7-35 \mathrm{~km})$ in the months January, April, July, and October for the years 2006-2015. 


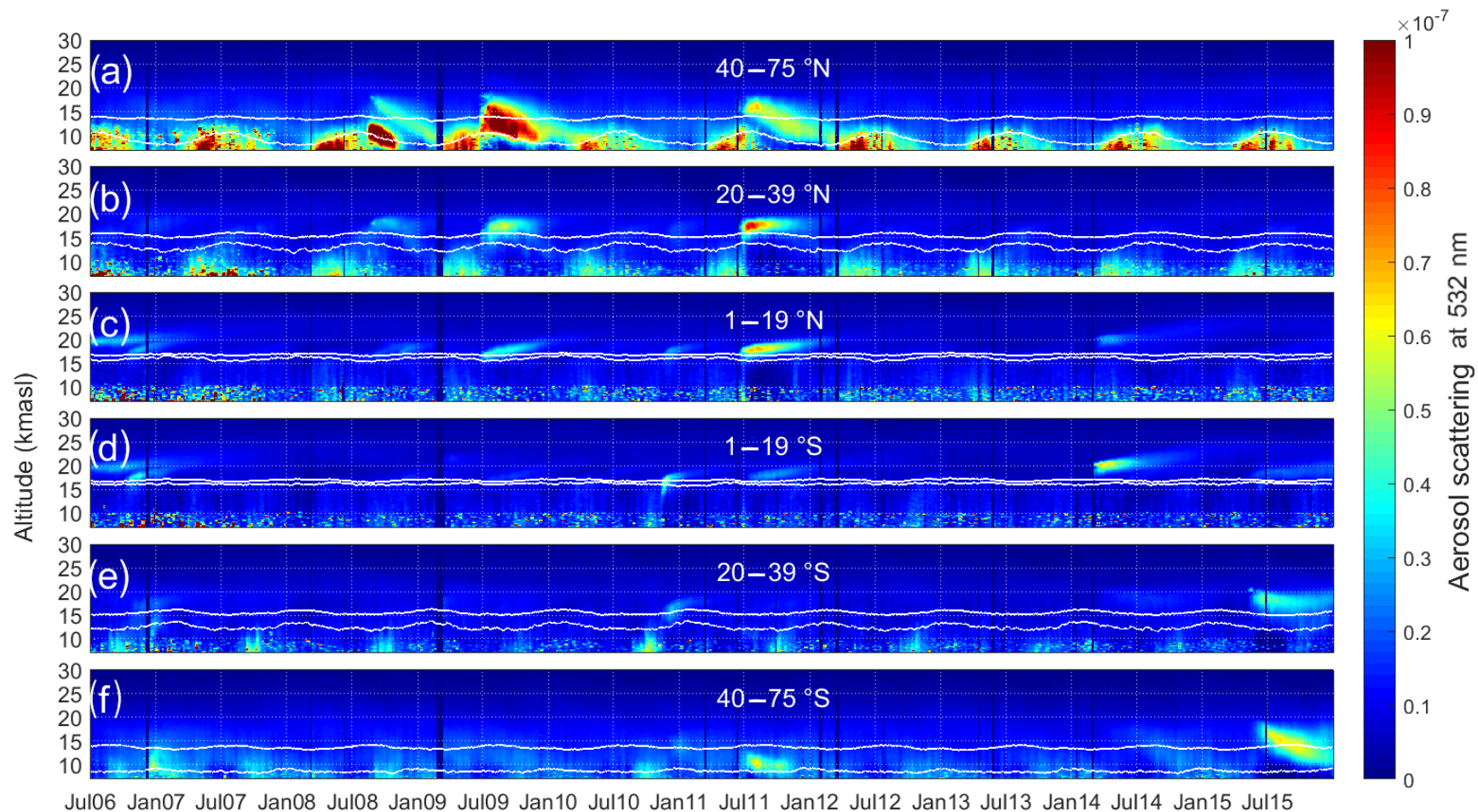

Figure 5. Aerosol scattering against time and altitude in six latitude bands, each covering $16 \%$ of the Earth's surface area. The white lines mark the mean altitudes of the tropopause and the $380 \mathrm{~K}$ isentrope.

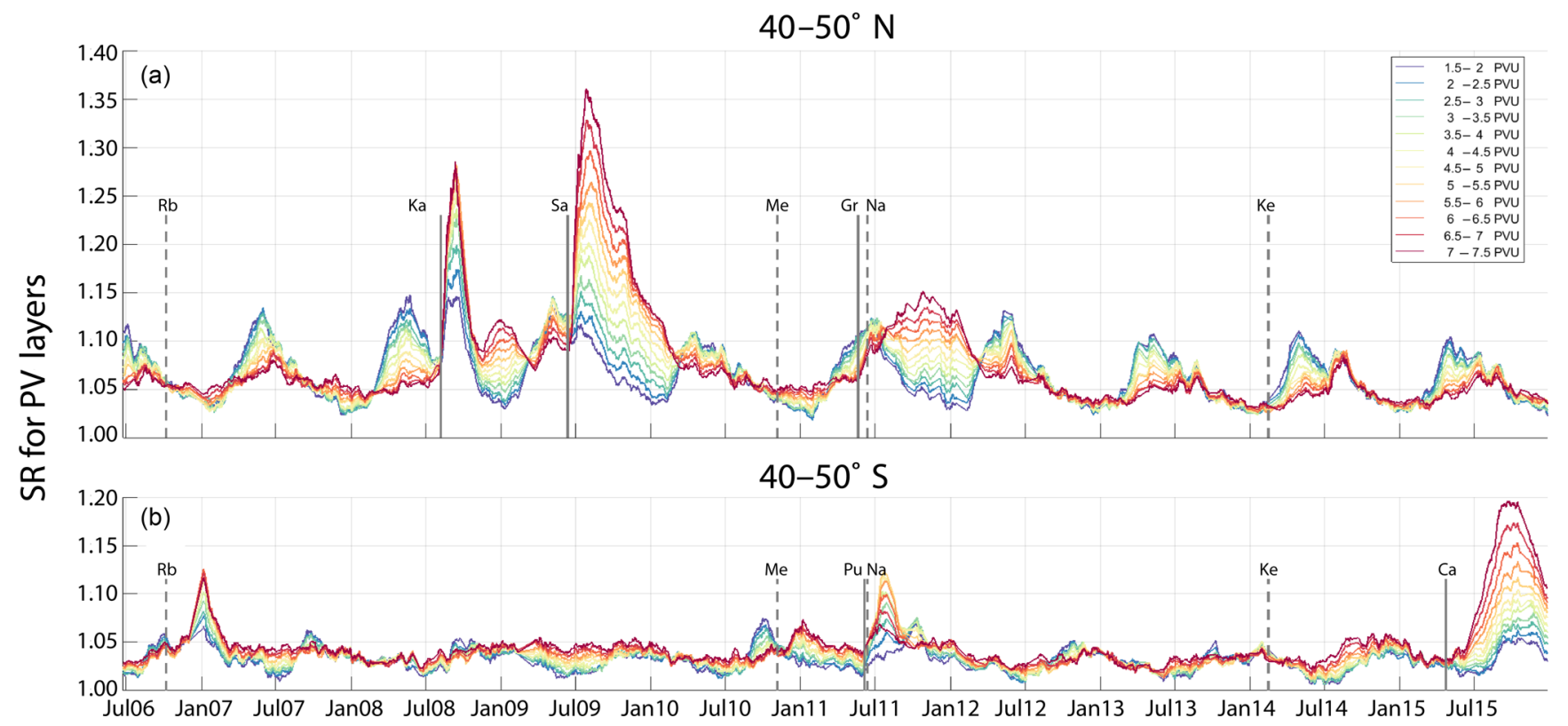

Figure 6. Temporal trends of the scattering ratio in altitude layers in the lower part of the LMS (PV intervals of 0.5 PVU), for the latitude bands $40-50^{\circ} \mathrm{N}$ (a) and 40-50 $\mathrm{S}$ (b). Vertical solid lines mark extratropical volcanic eruptions, and dashed lines indicate tropical eruptions that impacted the respective Hemisphere. 
injected large amounts of volcanic aerosol in the lower parts of the LMS and the UT. As a result, the aerosol signal is strong also in the lowest LMS layer of Fig. 6a (1.5-2 PVU).

The local tropospheric sources' contribution to the stratospheric aerosol load are small in comparison to the signals of strong volcanic eruptions from Kasatochi, Sarychev, or Calbuco, making them negligible in the perspective of the stratosphere's total AOD. They do, however, have significant relative influence on the ExTL in the absence of strong volcanic eruptions.

The value of 1.5 PVU is the lowest dynamic tropopause commonly used, and based on the investigation above, a PV value of 1.5 PVU was chosen to represent the dynamic tropopause in the following analyses, as it best captures the "full" volcanic impact on the stratosphere and on the climate.

\subsection{Volcanic and tropospheric impact in the ExTL}

Many interesting features can be seen in comparisons of the atmospheric slices in the lower part of the LMS (Fig. 6) and of the two hemispheres. The largest peaks in the SR occurred after major volcanic eruptions in the extratropics (Kasatochi, Sarychev, and Calbuco), which affected their respective hemispheres. In the aftermath, the SR is highest deep into the LMS (at the highest PVs) and decreases down to the tropopause. This gradient is caused by gradual mixing of stratospheric air, carrying volcanic aerosol, with cleaner tropospheric air.

In the absence of major volcanic eruptions, the highest $\mathrm{SR}$ is found in spring close to the tropopause. Thus, the SR gradient is reversed compared to the periods dominated by volcanism, and it is more evident in the Northern than in the Southern Hemisphere. Figure 5 shows that the gradient is connected to a springtime-summertime increase in AS in the troposphere. Hence, we conclude that tropospheric local sources have significant influence in the ExTL during spring. These sources are obviously less important in the Southern Hemisphere. Aircraft measurements in the ExTL revealed that upwelling dust peaks in spring (Martinsson et al., 2005). These observations suggest that the spring-summer peaks in the lowest part of the LMS are caused by upwelling dust. Its impact on the total stratosphere is small and is rapidly decreasing in strength in the first $2 \mathrm{~km}$ above the tropopause (1.5-5.5 PVU, the ExTL). Fluctuations caused by local tropospheric sources therefore have only a minor influence on the stratospheric aerosol.

\section{Discussions}

The stratospheric AOD is obtained by converting aerosol scattering to extinction based on the particle size distribution and chemical composition (Jäger and Deshler, 2002, 2003) and integrating in the vertical direction. The patterns of volcanism are evident in Fig. 7 where we divided the strato- sphere into three layers for which we calculated AOD. This sub-division was based on transport patterns: the upper layer extends down to the $470 \mathrm{~K}$ isentrope, and represents the region where the latitudinal transport is weak (Fueglistaler et al., 2009; Lin and Fu, 2013), the LMS constitute the lowest layer, and in between is the midlayer-spanning isentropes of $380-470 \mathrm{~K}$, where the shallow Brewer-Dobson branch is strong. This categorization of stratospheric layers will be used in the following discussions.

The temporal trends of the global and hemispheric mean AODs are compared in Fig. 8 for the three layers and for that of the "entire" stratosphere. Even though the LMS is mostly confined to the extratropics, and altitudes above $470 \mathrm{~K}$ constitute a small portion of the stratospheric mass, it is evident that aerosol in these layers make up a significant portion of the global stratospheric AOD. In times of low volcanic impact the three layers contribute in approximately equal amounts to the total stratospheric AOD. Furthermore, Figs. 7 and 8 show that the global stratospheric AOD reached its lowest values in the studied decade around the year 2013. This is in agreement with in situ observations that find the stratospheric aerosol load to be at background conditions in 2013 (Martinsson et al., 2017).

We further explore the AOD distribution by investigating the strong latitudinal patterns shown in Fig. 7. This is illustrated in Fig. 9, where the AOD was averaged over different time periods. In Fig. 9a we find the AOD to be distributed very differently in the respective layers. The upper layer has its highest AOD in the tropics and it decreases towards the poles. The LMS naturally shows the highest AODs in the extratropics. The largest elevations in the LMS AOD relative to background conditions are observed in the Northern Hemisphere due to stronger volcanic influence. The midlayer is shown to have more evenly distributed AOD, with slightly higher AOD in the extratropics, and the highest in the Northern Hemisphere. In Fig. 9b-d we separate the layers, to compare the influence from three types of volcanic eruptions to that of the decadal mean and that of the background conditions (year 2013).

\subsection{The different eruption types}

It is evident that the impact on the stratospheric AOD varied between eruptions and that only a few eruptions reached into the uppermost layer. The eruptions that had significant impact on the stratospheric AOD were grouped into three categories depending on the observations in Fig. 7. These types are as follows:

- Trop I - Tropical eruptions with deep-reaching volcanic clouds, which were to a large degree incorporated into the deep Brewer-Dobson branch and ascended in the tropical pipe.

- Trop II - Tropical eruptions with clouds that were confined in the midlayer, transported in the shallow 


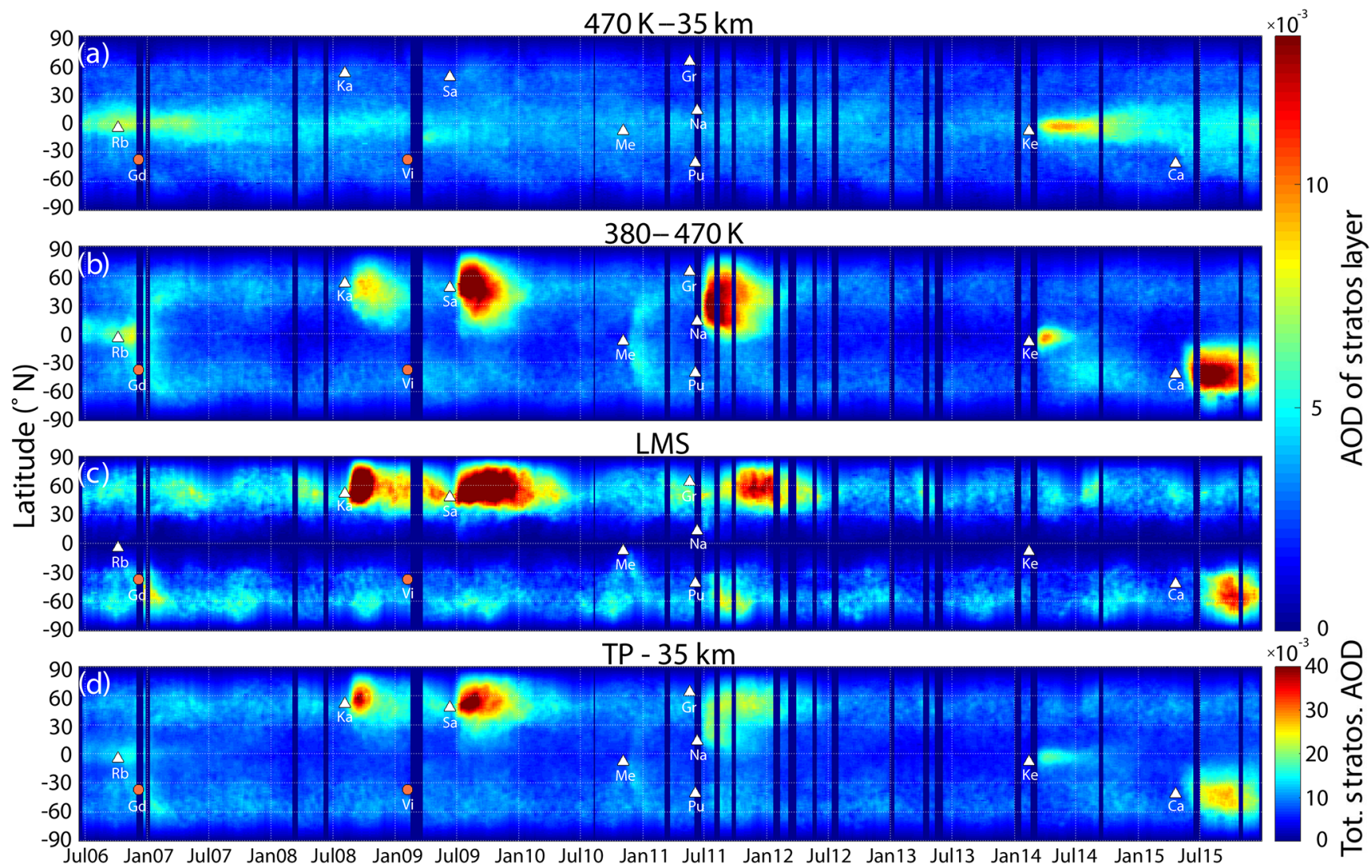

Figure 7. The latitudinal distribution over 10 years for the latitude-weighted stratospheric AOD: (a) above the $470 \mathrm{~K}$ isentrope, (b) between the 380 and $470 \mathrm{~K}$ isentropes, (c) the LMS, and (d) that of the entire stratosphere. The color bar for panels (a)-(c) spans a range of one-third that in panel (d). Abbreviations and triangles (circles) mark time and latitude of relevant volcanic eruptions (forest fires).

Brewer-Dobson branch, and not significantly transported in the deep branch.

- Extrop - Volcanic clouds from extratropical eruptions. Some of these were confined within the LMS, and others partly penetrated into the midlayer where the aerosol was incorporated into the shallow BrewerDobson branch and spread to the tropics.

The impact of the volcanic eruptions will be discussed based on these categories in the following sections, along with the two wildfires.

\subsubsection{Deep reaching tropical volcanic eruptions}

Two volcanoes significantly affected the upper layer (Fig. 7a), i.e Soufrière Hills (May 2006) and Kelut (February 2014). In addition, part of the elevations in AOD from summer 2006 may have come from the January 2005 Manam eruption (Vernier et al., 2009). The high-reaching part of the Soufrière Hills cloud slowly ascended in the tropics. A strong elevation of the AOD is visible for more than 1.5 years after the eruption, after which the AOD decreases slowly over the following years until reaching its lowest values in 2013. The
Kelut volcano erupted after this period of stratospheric background levels, making it easy to track the spread of the volcanic aerosol. A large fraction of the volcanic cloud slowly ascended with the deep Brewer-Dobson branch in the tropical pipe, whereas the lower part of it was spread latitudinally in the midlayer, mostly to the southern extratropics (Figs. 4 and 9). The high-altitude part of the cloud was confined within the tropics. A small sudden increase in the AOD is observed in the southern extratropics (Fig. 7a), approximately 1.5 years after the Kelut eruption. The elevation is shown as in Fig. 7a and was likely connected with aerosol injected by the midlatitude eruption of Calbuco (April 2015). The aerosol load of the upper layer shows minor fluctuations which can be caused by evaporation or condensation of sulfuric acid (Vernier et al., 2011) in the upper part of the layer in connection with temperature variability induced by the quasi-biennial oscillation (Hommel et al., 2015). The aerosol in the upper layer is eventually transported out to the next lower layer at midlatitudes, i.e the one confined between the 380 and $470 \mathrm{~K}$ isentropes. We observe this in the $380-470 \mathrm{~K}$ layer in northern midlatitudes (Fig. 7b), where the AOD was 

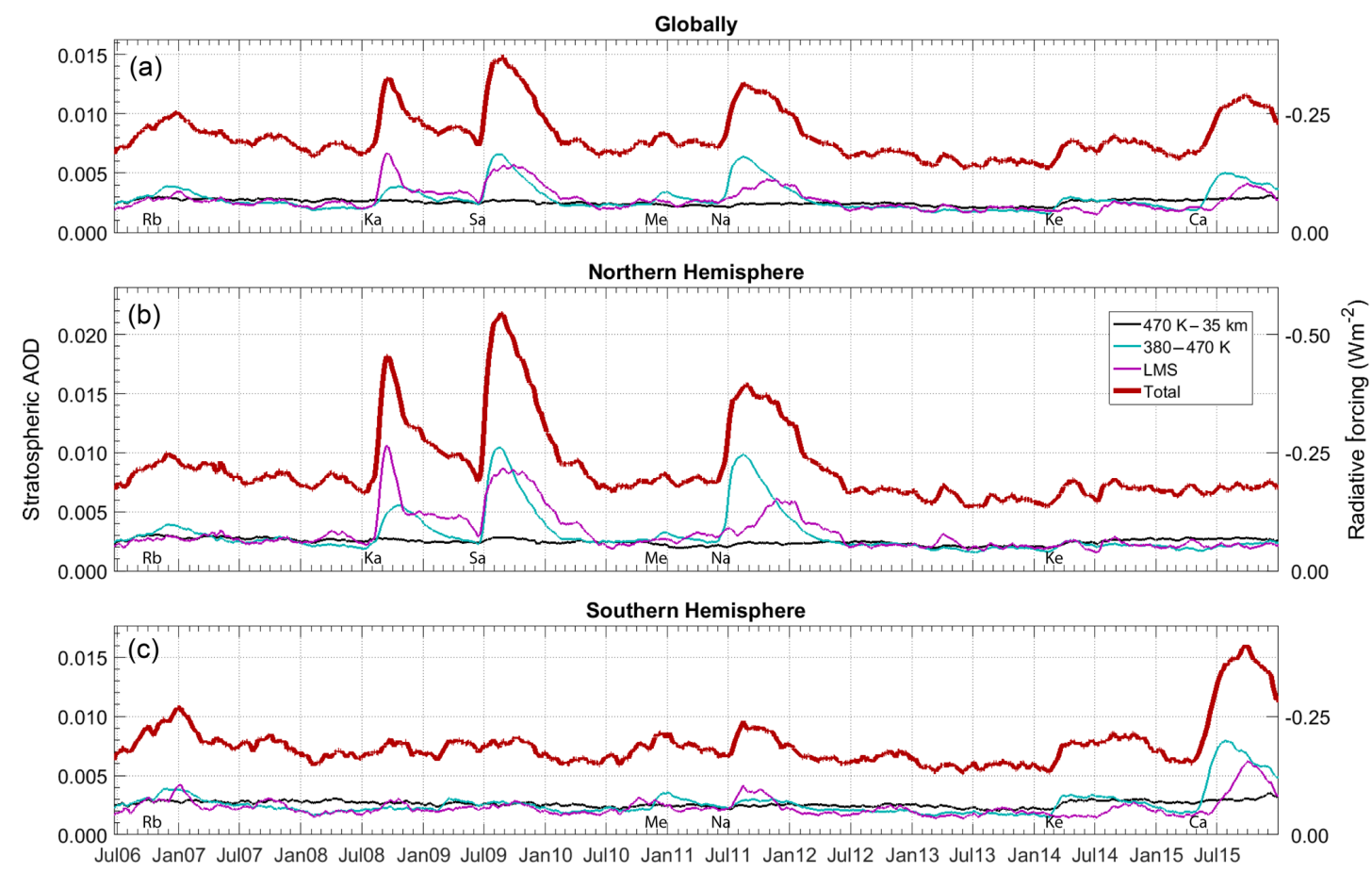

Figure 8. Temporal trends of the stratospheric AOD and radiative forcing for (a) the entire globe, (b) the Northern Hemisphere, and (c) the Southern Hemisphere. The lines mark the AOD of the LMS (magenta), altitudes between the 380 and $470 \mathrm{~K}$ isentropes (cyan), altitudes above the $470 \mathrm{~K}$ isentrope (black), and the entire stratosphere (thick red). Significant volcanic eruptions are indicated by their abbreviations. Note the reversed scale for the radiative forcing on the right $y$ axis. Data were extrapolated to the polar regions and latitude weighted before averaging.

higher in the year 2007 and beginning of 2008 compared to the background (year 2013).

\subsubsection{Tropical eruptions below the $470 \mathrm{~K}$ isentrope}

The volcanic clouds of the tropical eruptions from Rabaul (October 2006), Merapi (November 2010), and Nabro (June 2011) all penetrated the tropopause but did not reach altitudes above the $470 \mathrm{~K}$ isentrope $(\sim 20 \mathrm{~km})$. While the two former eruptions impacted both hemispheres, the Nabro eruption mostly influenced the Northern Hemisphere (Figs. 7 and 9). The small increase shown after Nabro in the Southern Hemisphere LMS (Fig. 9) was caused by the extratropical eruption of Puyehue-Cordón Caulle (June 2011). The aerosol from the Trop II eruptions was incorporated into the shallow Brewer-Dobson branch and spread to the midlatitudes within weeks. There the volcanic aerosol subsided and increased the AOD of the LMS, while decreasing in the midlayer (Figs. 7 and 8). The AOD in the midlayer decreased over $\sim 9$ months in the case of the strong Nabro eruption, and the subsidence through the LMS resulted in several months prolonging of the volcanic impact of the eruption (Figs. 7 and 8).

\subsubsection{Extratropical volcanic clouds}

Several extratropical eruptions impacted the northern hemispheric stratosphere, and some influenced the southern one. In the Northern Hemisphere, Kasatochi (August 2008) and Sarychev (June 2009) induced the strongest elevations in the AOD. Part of the aerosol from these eruptions reached the midlayer, where it was spread to the tropical stratosphere within the shallow Brewer-Dobson branch. Figure 8 shows that some patterns of the global and northern hemispheric mean AOD in the midlayer after Sarychev are similar to that of the Nabro eruption. The latitudinal distributions in the midlayer shows similarities (Fig. 9c), but being a tropical eruption Nabro naturally had a greater impact in the tropics.

The Kasatochi eruption formed two clouds. Kasatochi's dense lower cloud was confined to the LMS and UT. Its stratospheric part was transported to the tropopause within approximately 3 months. The remaining weaker signal comes from the upper cloud that descended to the LMS (Fig. 8). The upper cloud reached the 380-470 K layer, and shows some similarities with that from the Sarychev and Nabro eruptions, having a rapid latitudinal transport in the lower BD branch. For all three eruptions, the elevation of the AOD remained until the following spring until the strong subsidence transported the aerosol down to the troposphere. 
(a)

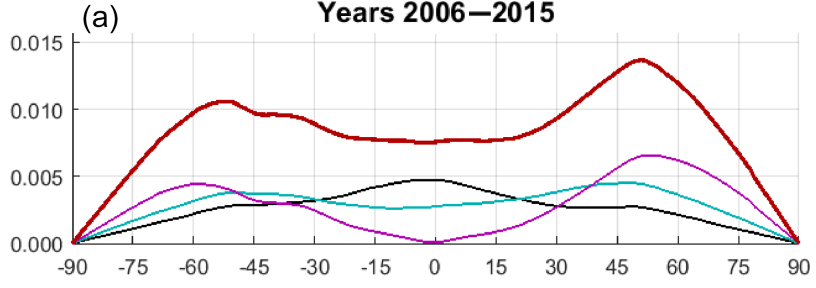

(b)

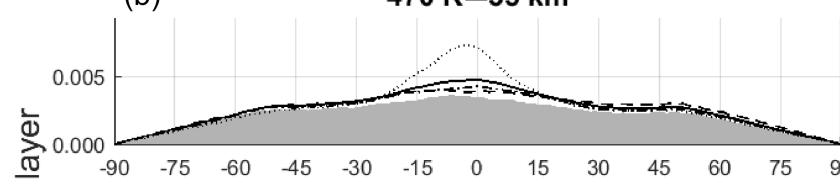

$\frac{\text { ț }}{4}$

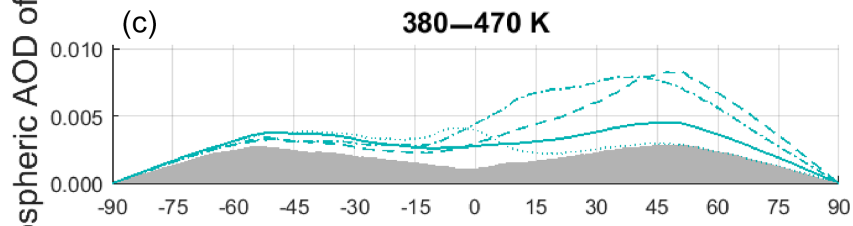

(d)

LMS

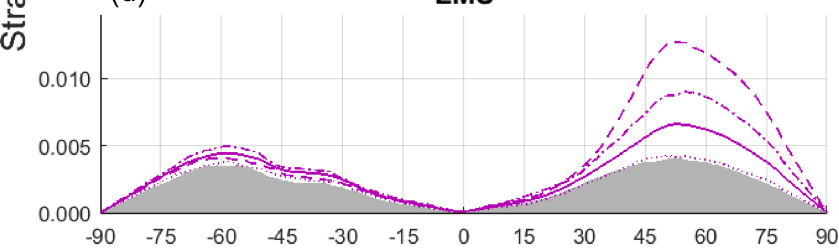

(e)

TP - 35 km

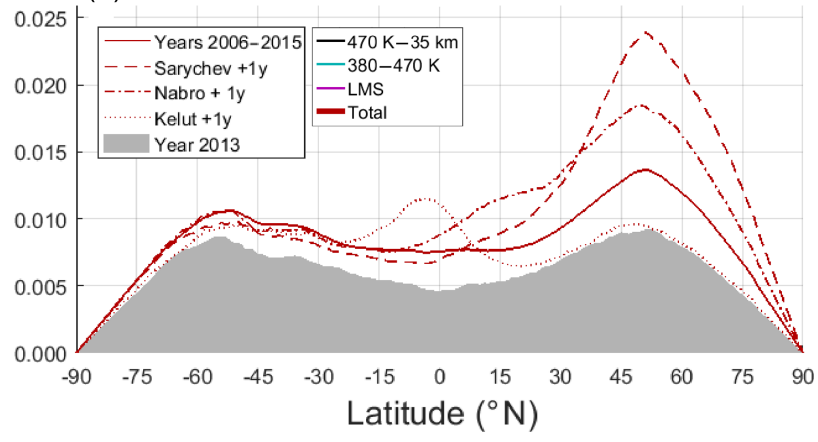

Figure 9. The latitudinal distribution of the latitude-weighted AOD. (a) The AOD of the different stratospheric layers and of the total stratospheric AOD (thick red) for the entire period (2006-2015). (b)-(d) The respective layers and (e) the AOD of the entire stratospheric column, for the time periods noted in the legend. Lines represent AODs in the altitude intervals $470 \mathrm{~K}$ to $35 \mathrm{~km}$ (black), 380 $470 \mathrm{~K}$ (cyan), the LMS (magenta), and the entire stratosphere (thick red). The year 2013 (grey filling) is considered as background condition, and the line styles mark the different periods, as noted in the legend.

The Calbuco eruption (April 2015) was by far the largest one in the Southern Hemisphere. The volcanic cloud reached above the LMS and induced a rapid strong elevation of the AOD of the midlayer. The subsiding aerosol increased the AOD of the LMS so that it peaked a few months later than in the midlayer. Calbuco reached higher altitudes than
Kasatochi and Sarychev did, explaining the slower transport down to the LMS.

There were also a number of minor influences from extratropical volcanic eruptions that are shown as small increases in Figs. 7 and 8, e.g., the eruptions of Redoubt (March 2009), Grimsvötn (May 2011), and Puyehue-Cordón Caulle (June 2011). Their clouds contained lower amounts of aerosol and did not penetrate as deep into the stratosphere, as did the extratropical eruptions discussed above. Hence, the aerosol was rapidly transported out of the stratosphere, similarly to the lower cloud following the Kasatochi eruption.

\subsubsection{The forest fires}

The two forest fires affecting the stratosphere in this 10-year period had a significantly lower impact on the stratospheric AOD than the volcanic eruptions. The fire in February 2009 reached altitudes of more than $20 \mathrm{~km}$ (Figs. 4 and 7a). A concurrent small increase in the AOD is shown in the southern tropical upper layer (Fig. 7a), which is mixed with the volcanic aerosol from the Soufrière Hills eruption. This fire therefore could have made a small but long-term impact on the stratospheric AOD. The fire in December 2006 mainly affected the southern LMS, as evidenced in Fig. 6c, with a duration of a few months.

\subsection{Patterns of volcanic aerosol in the stratosphere}

Summarizing the findings of volcanic perturbations and transport within the stratosphere, we make the following observations:

1. Aerosol from extratropical eruptions injected into the LMS remains there until transported out to the troposphere, e.g., the lower Kasatochi (2008) cloud. The AOD is elevated for less than a year.

2. Volcanic injections close to the extratropical tropopause only briefly impacts the stratospheric aerosol load, for example Grimsvötn (May 2011).

3. Aerosol from extratropical eruptions reaching the midlayer gets dispersed hemispherically, and will be found at higher altitude in the tropics than their extratropical injection altitude, but no clear case of interhemispheric exchange. Examples are the upper Kasatochi cloud, the upper part of the Sarychev (2009) cloud and Calbuco (2015).

4. Volcanic clouds from tropical eruptions reaching above the $470 \mathrm{~K}$ isentrope (approximately $20 \mathrm{~km}$ altitude) tend to move upwards without a strong poleward transport, e.g., Soufrière Hills (2006) and Kelut (2014). Hence, the aerosol remains in the stratosphere for several years.

5. Volcanic clouds injected close to the tropical tropopause tend primarily to be transported poleward and within 
1-2 months reach midlatitudes, e.g., Rabaul (2006), Merapi (2010), and Nabro (2011). The Nabro eruption shows that the AOD was elevated for approximately 1 year. For the other two eruptions the signals are too weak for such estimations.

6. The last, clear indications of influence from extratropical as well as tropical volcanic eruptions appear in the LMS at mid- and high latitudes, as manifested by the three largest eruptions in this study (according to Table 1), i.e., Kasatochi, Sarychev, and Nabro.

These observations agree well with the large-scale circulation pattern in the stratosphere. The general circulation of the stratosphere (Brewer-Dobson) is directed upwards in the tropics and downwards in the extratropics. As a consequence volcanic clouds injected into the LMS, which is not isentropically connected with other parts of the stratosphere, are transported downwards to the troposphere (point 1), and clouds injected close to the extratropical tropopause are rapidly removed due to that transport (2). Volcanic clouds reaching above approximately $20 \mathrm{~km}$ altitude in the tropics (4) get incorporated in the upper Brewer-Dobson branch and become relatively isolated from the extratropics for years (Fueglistaler et al., 2009), whereas tropical eruptions reaching lower altitudes are rapidly mixed meridionally (5) via the shallow Brewer-Dobson branch. This also explains the observation of reverse transport of extratropical volcanic clouds where aerosol reaching above the upper boundary of the LMS (3) is transported in the shallow Brewer-Dobson branch. Finally, the observation that the volcanic clouds of both tropical and extratropical eruptions leave the stratosphere via the LMS (6) is connected with the direction of the Brewer-Dobson circulation. Obviously, volcanic aerosol that reached the stratosphere ends up in the LMS sooner or later, no matter the injection latitude or altitude of the stratospheric injection.

\subsection{Comparison to other AOD data sets}

Our AODs were compared with AODs reported in other long-term studies. The comparison was undertaken by forming annual means for various parts of the stratosphere, and is summarized in Table 2. In the comparison we have computed AODs for the same stratospheric regions in terms of latitude and altitude intervals as used in the referenced data, with the exception that our tropopause differs from that of Thomason et al. (2018) by being in the order of $1 \mathrm{~km}$ lower altitude at midlatitudes. Our AODs are presented along with values on how much higher or lower the AODs are in the other studies. Khaykin et al. (2017) computed AODs between 17-30 km altitude at wavelength of $532 \mathrm{~nm}$ (same as that of CALIOP) by combining satellite and ground-based instruments. Their values are very similar to ours. We also compared our data to AODs at a wavelength of $525 \mathrm{~nm}$ (Rieger et al., 2015; Thomason et al., 2018), which are expected to be $2 \%$ higher than the AODs at $532 \mathrm{~nm}$ (Jäger and Deshler, 2002, 2003; Khaykin et al., 2017). Thomason et al. (2018) combined data from space-based platforms to obtain the AOD of the "entire" stratosphere, and their study extends until 2009. We compare the annual means of 2007, 2008, and 2009 that were produced by OSIRIS and CALIOP in their data set. Their southern midlatitude AODs are higher, and tropical AODs are slightly higher, than in our study. In the northern midlatitudes after the eruptions of Kasatochi (2008) and Sarychev (2009) the AODs from Thomason et al. (2018) are lower than AODs obtained in the present study. The relative importance of LMS aerosol in the Northern Hemisphere was elevated during 2008 and 2009, suggesting differences in the LMS aerosol quantification between their data sets and ours. In part this can be explained by differences in tropopause definition: they used a monthly mean thermal tropopause as their lower limit, whereas we use the local 1.5 PVU dynamic tropopause situated at lower altitude. The OSIRIS data in Thomason et al. (2018) come from the data set presented in Rieger et al. (2015). The AODs from the merged data set of SAGE II and OSIRIS in Rieger et al. (2015) are higher than ours. Their AOD data were converted from retrievals at a wavelength of $750 \mathrm{~nm}$ with commonly used assumptions on the aerosol properties. The CALIOP/GOMOS data in the same paper show higher AODs than ours in 2007 and 2008, whereas the data agree well with ours from 2009-2013. Finally, the stratospheric AODs in the GISS climate model denoted OSIRIS/Sato in Table 2, also obtained from Rieger et al. (2015), are lower than those presented here.

Some obvious differences between the data sets, such as differences in measurement techniques, can explain part of the difference. Detailed knowledge on stratospheric aerosol composition, size distribution, and optical properties is needed to improve the accuracy of stratospheric AOD retrievals from all the satellite-based instruments in this comparison. This problem requires further attention, but is outside the scope of this paper.

\subsection{Climate relevance}

Comparison of the mean AOD for 2006-2015 to that in the background (the year 2013) reveals that the volcanic eruptions increased the stratospheric AOD by $\sim 40 \%$ (Table 3). The eruptions of the extratropical Sarychev and tropical Nabro volcanoes both increased the AOD by $\sim 70 \%$ over the course of a year. The higher-reaching Kelut eruption had a smaller initial influence, i.e., $\sim 20 \%$ in the first year after eruption. It is expected to impact the stratospheric AOD over several years due to the slow transport in the deep BrewerDobson branch. Averaged over longer time spans the Kelut eruption likely caused an impact on the stratospheric AOD of similar size as the more sulfur-rich eruptions of Sarychev and Nabro.

The resulting radiative forcing was estimated as in Hansen et al. (2005) and Solomon et al. (2011), using a conversion 
Table 2. Comparison of the annual mean AODs from our study and other studies, for the years 2007-2013 and various latitude intervals.

\begin{tabular}{|c|c|c|c|c|c|c|c|c|c|c|}
\hline \multirow[b]{2}{*}{ Instruments } & \multirow[b]{2}{*}{ Lat. intervals } & \multirow[b]{2}{*}{ Altitude ${ }^{\mathrm{d}}$} & \multicolumn{8}{|c|}{ AOD in present study (other groups deviations from our AODs) } \\
\hline & & & 2007 & 2008 & 2009 & 2010 & 2011 & 2012 & 2013 & All years \\
\hline \multirow{6}{*}{$\begin{array}{l}\text { CALIOP/ } \\
\text { OSIRIS }^{\mathrm{a}}\end{array}$} & $35-45^{\circ} \mathrm{N}$ & $\mathrm{TP}-35 \mathrm{~km}^{\mathrm{c}}$ & 0.0100 & 0.0128 & 0.0181 & & & & & 0.0136 \\
\hline & & & $(-4.8 \%)$ & $(-7.2 \%)$ & $(-7.8 \%)$ & & & & & $(-4.4 \%)$ \\
\hline & $5^{\circ} \mathrm{S}-5^{\circ} \mathrm{N}$ & $\mathrm{TP}-35 \mathrm{~km}^{\mathrm{c}}$ & 0.0052 & 0.0044 & 0.0052 & & & & & 0.0049 \\
\hline & & & $(15 \%)$ & $(20 \%)$ & $(18 \%)$ & & & & & $(17 \%)$ \\
\hline & $35-45^{\circ} \mathrm{S}$ & $\mathrm{TP}-35 \mathrm{~km}^{\mathrm{c}}$ & 0.0093 & 0.0082 & 0.0088 & & & & & 0.0088 \\
\hline & & & $(29 \%)$ & $(38 \%)$ & $(32 \%)$ & & & & & $(32 \%)$ \\
\hline \multirow[t]{2}{*}{ OSIRIS $^{\mathrm{b}}$} & $50^{\circ} \mathrm{S}-50^{\circ} \mathrm{N}$ & $1 \mathrm{~km}$ above & 0.0046 & 0.0041 & 0.0048 & 0.0039 & 0.0050 & 0.0039 & 0.0031 & 0.0042 \\
\hline & & $380 \mathrm{~K}-35 \mathrm{~km}$ & $(32 \%)$ & $(19 \%)$ & $(17 \%)$ & $(21 \%)$ & $(25 \%)$ & $(27 \%)$ & $(22 \%)$ & $(23 \%)$ \\
\hline \multirow{2}{*}{$\begin{array}{l}\text { CALIOP/b } \\
\text { GOMOS }\end{array}$} & $50^{\circ} \mathrm{S}-50^{\circ} \mathrm{N}$ & $15-35 \mathrm{~km}$ & 0.0051 & 0.0047 & 0.0056 & 0.0045 & 0.0060 & 0.0043 & 0.0036 & 0.0048 \\
\hline & & & $(30 \%)$ & $(23 \%)$ & $(0.3 \%)$ & $(10 \%)$ & $(0.1 \%)$ & $(12 \%)$ & $(12 \%)$ & $(12 \%)$ \\
\hline \multirow{2}{*}{$\begin{array}{l}\text { OSIRIS/ } \\
\text { Sato }^{b}\end{array}$} & $50^{\circ} \mathrm{S}-50^{\circ} \mathrm{N}$ & $15-35 \mathrm{~km}$ & 0.0051 & 0.0047 & 0.0056 & 0.0045 & 0.0060 & 0.0043 & & 0.0048 \\
\hline & & & $(-7.7 \%)$ & $(-19 \%)$ & $(-16 \%)$ & $(-16 \%)$ & $(-12 \%)$ & $(-8.2 \%)$ & & $(-13 \%)$ \\
\hline \multirow{3}{*}{$\begin{array}{l}\text { GOMOS/ } \\
\text { OSIRIS/ } \\
\text { CALIOP }^{\mathrm{e}}\end{array}$} & $40-50^{\circ} \mathrm{N}$ & $17-30 \mathrm{~km}$ & 0.0037 & 0.0041 & 0.0045 & 0.0035 & 0.0040 & 0.0034 & 0.0029 & 0.0037 \\
\hline & & & $(0.0 \%)$ & $(-6.8 \%)$ & $(-4.8 \%)$ & $(-8.4 \%)$ & $(-6.6 \%)$ & $(1.4 \%)$ & $(-10 \%)$ & $(-5.0 \%)$ \\
\hline & & & & & & & & & & \\
\hline
\end{tabular}

${ }^{\mathrm{a}}$ Thomason et al. (2018). ${ }^{\mathrm{b}}$ Rieger et al. (2015), higher lidar ratio than $50 \mathrm{sr}$ for CALIOP. ${ }^{\mathrm{c}}$ TP refers to the tropopause in the comparison with Thomason et al. (2018).

$\mathrm{d}$ Thomason et al. (2018) used a climatic tropopause, whereas we used the dynamic tropopause at 1.5 PVU. ${ }^{\mathrm{e}}$ Khaykin et al. (2017), mean of satellite retrievals, lidar ratio of 50 sr for CALIOP.

Table 3. Global mean stratospheric AOD and radiative forcing for the years 2006-2015, the year 2013, and the first year after the volcanic eruptions in Fig. 9.

\begin{tabular}{lrr}
\hline Period & AOD & $\mathrm{RF}\left(\mathrm{W} \mathrm{m}^{-2}\right)$ \\
\hline Years 2006-2015 & 0.0082 & -0.21 \\
The year 2013 & 0.0059 & -0.15 \\
Sarychev +1 year & 0.0102 & -0.26 \\
Nabro +1 year & 0.0099 & -0.25 \\
Kelut +1 year & 0.0073 & -0.18 \\
\hline
\end{tabular}

factor of -25 for AOD to radiative forcing, and is added to Fig. 8 as a secondary $y$ axis. The global radiative forcing from stratospheric aerosol ranged from approximately -0.15 in the background to $-0.35 \mathrm{~W} \mathrm{~m}^{-2}$ after the strongest volcanic eruptions of the period (Fig. 8). Most of the elevation in radiative forcing appeared in the Northern Hemisphere, with the lowest occurring during the year 2013. On average the global stratospheric radiative forcing amounted to $-0.2 \mathrm{~W} \mathrm{~m}^{-2}$ during a time period of a decade (Table 3 ).

\section{Conclusions}

We present a study on the stratospheric aerosol optical depth (AOD) and radiative forcing over a period of almost a decade (mid-2006-2015), covering periods of varying volcanic impact as well as stratospheric background conditions, with a resolution of $1^{\circ}$ latitudinally and 8 days timewise. This required the development of new methods to prevent influence from polar stratospheric clouds, and to correct data when the lidar was attenuated by volcanic aerosol. The latter correction increased the AOD by 4-7\% in the first year after the volcanic eruptions of Kasatochi (2008), Sarychev (2009), Nabro (2011), and Calbuco (2015). We find that our stratospheric AODs generally compare well with values reported in other long-term studies. This comparison was undertaken for various parts of the stratosphere. Looking at the reported total stratospheric AODs, the results reported here are usually the highest, because our data sets, in contrast to most of the others, include the LMS.

Strong volcanic impact was found in the extratropical tropopause layer (ExTL) down to potential vorticities (PV) of 1.5 PVU, i.e., more than $1 \mathrm{~km}$ below the thermal tropopause. We therefore used the 1.5 PVU level as the tropopause in our analysis to include the full impact of volcanism. In springsummer, upwelling dust clearly elevated the aerosol load, up to PV levels of 5-6PVU, i.e., $\sim 2 \mathrm{~km}$ above the dynamic tropopause, but it had insignificant influence on the total AOD of the lowermost stratosphere (LMS).

The stratospheric AOD was studied by dividing the stratosphere into three layers that incidentally carry approximately the same global AOD during conditions close to the stratospheric background: the LMS, the altitude range between the 380 and $470 \mathrm{~K}$ isentropes, and altitudes above the $470 \mathrm{~K}$ isentrope $(\sim 20-35 \mathrm{~km})$. Several eruptions were found to influence the two lower layers, both extratropical and tropical ones.

Only the high-reaching aerosol from the tropical volcanoes Soufrière Hills (May 2006) and Kelut (February 2014) clearly impacted the upper layer $(>470 \mathrm{~K})$. Their volcanic clouds were first observed at altitudes of $\sim 20 \mathrm{~km}$, after which the clouds rose to higher altitudes incorporated in the deep Brewer-Dobson branch, impacting on the stratospheric AOD over several years. After the Soufrière Hills eruption 
the aerosol gradually decreased over the following years, which has also been observed for the far stronger Pinatubo eruption (1991). A similar decay was observed after the Kelut eruption, until the end of the period studied here.

Volcanic clouds reaching into the midlayer (380-470 K) were not found to rise, but spread latitudinally in the shallow Brewer-Dobson branch, before being transported down to the LMS and eventually out of the stratosphere in the extratropics. For example, aerosol from the eruptions of the extratropical volcanoes Sarychev (June 2009) and Calbuco (April 2015) spread to the tropics within weeks, whereas aerosol from the eruption of the tropical volcano Nabro (June 2011) spread in the opposite direction followed by subsiding to the LMS. Such transport was limited within a Hemisphere and impacted the stratosphere for up to a year.

The stratospheric AOD was elevated the most in the extratropics, due to the combined effect of latitudinal transport and the larger stratospheric column. The majority of that elevation came from aerosol located in the LMS. Subsidence through the LMS causes the AOD to remain elevated in the LMS for several months, after which the overlying stratosphere has returned to its background aerosol levels.

We have included the LMS in an estimation of the AOD of the "entire" stratosphere over the period 2006-2015. The stratospheric background AOD and the volcanic impact were found to be $\sim 50 \%$ higher in midlatitudes than in the tropics. Volcanism was found to have elevated the average global stratospheric AOD by $\sim 40 \%$. The stratospheric aerosol had a cooling effect of the Earth, which in terms of radiative forcing is estimated to be $-0.2 \mathrm{~W} \mathrm{~m}^{-2}$.

Data availability. AOD data are available upon request to the lead author.

Author contributions. JF performed the data processing and analysis, and wrote the paper. BGM, SMA and OSS contributed in discussions of the analysis and manuscript.

Competing interests. The authors declare that they have no conflict of interest.

Acknowledgements. Financial support from the Swedish National Space Board (contract 130/15) and the Swedish Research Council for Environment, Agricultural Sciences and Spatial Planning (contract 942-2015-995) is gratefully acknowledged. Aerosol products from the CALIOP sensor were produced by NASA Langley Research Center.

Edited by: Michael Pitts

Reviewed by: two anonymous referees

\section{References}

Andersson, S. M., Martinsson, B. G., Vernier, J. P., Friberg, J., Brenninkmeijer, C. A. M., Hermann, M., Van Velthoven, P. F. J., and Zahn, A.: Significant radiative impact of volcanic aerosol in the lowermost stratosphere, Nat. Commun., 6, 1-8, https://doi.org/10.1038/ncomms8692, 2015.

Baldwin, M. P., Gray, L. J., Dunkerton, T. J., Hamilton, K., Haynes, P. H., Randel, W. J., Holton, J. R., Alexander, M. J., Hirota, I., Horinouchi, T., Jones, D. B. A., Kinnersley, J. S., Marquardt, C., Sato, K., and Takahashi, M.: The quasi-biennial oscillation, Rev. Geophys., 39, 179-229, https://doi.org/10.1029/1999RG000073, 2001.

Bönisch, H., Engel, A., Curtius, J., Birner, Th., and Hoor, P.: Quantifying transport into the lowermost stratosphere using simultaneous in-situ measurements of $\mathrm{SF}_{6}$ and $\mathrm{CO}_{2}$, Atmos. Chem. Phys., 9, 5905-5919, https://doi.org/10.5194/acp-9-5905-2009, 2009.

Bourassa, A. E., Robock, A., Randel, W. J., Deshler, T., Rieger, L. A., Lloyd, N. D., Llewellyn, E. J., and Degenstein, D. A.: Large Volcanic Aerosol Load in the Stratosphere Linked to Asian Monsoon Transport, Science, 337, 78-81, https://doi.org/10.1126/science.1219371, 2012.

Brühl, C., Lelieveld, J., Crutzen, P. J., and Tost, H.: The role of carbonyl sulphide as a source of stratospheric sulphate aerosol and its impact on climate, Atmos. Chem. Phys., 12, 1239-1253, https://doi.org/10.5194/acp-12-1239-2012, 2012.

Carn, S. A. and Prata, F. J.: Satellite-based constraints on explosive $\mathrm{SO}_{2}$ release from Soufrière Hills Volcano, Montserrat, Geophys. Res. Lett., 37, 1-5, https://doi.org/10.1029/2010GL044971, 2010.

Carn, S. A., Paluster, J. S., Lara, L., Ewert, J. W., Watt, S., Prata, A. J., Thomas, R. J., and Villarosa, G.: The Unexpected Awakening of Chaitén Volcano, Chile, Eos, 90, 205-206, https://doi.org/10.1029/2009EO240001, 2009.

Clarisse, L., Hurtmans, D., Clerbaux, C., Hadji-Lazaro, J., Ngadi, Y., and Coheur, P.-F.: Retrieval of sulphur dioxide from the infrared atmospheric sounding interferometer (IASI), Atmos. Meas. Tech., 5, 581-594, https://doi.org/10.5194/amt-5-5812012, 2012.

Crutzen, P. J.: The possible importance of COS for the sulphate layer of the stratosphere, Geophys. Res. Lett., 3, 73-76, 1976.

Deshler, T.: A review of global stratospheric aerosol: Measurements, importance, life cycle, and local stratospheric aerosol, Atmos. Res., 90, 223-232, https://doi.org/10.1016/j.atmosres.2008.03.016, 2008.

Friberg, J., Martinsson, B. G., Andersson, S. M., Brenninkmeijer, C. A. M., Hermann, M., Van Velthoven, P. F. J., and Zahn, A.: Sources of increase in lowermost stratospheric sulphurous and carbonaceous aerosol background concentrations during 1999-2008 derived from CARIBIC flights, Tellus B, 66, 23428, https://doi.org/10.3402/tellusb.v66.23428, 2014.

Fromm, M., Lindsey, D. T., Servranckx, R., Yue, G., Trickl, T., Sica, R., Doucet, P., and Godin-Beekmann, S.: The untold story of pyrocumulonimbus, B. Am. Meteorol. Soc., 91, 1193-1209, https://doi.org/10.1175/2010BAMS3004.1, 2010.

Fueglistaler, S., Dessler, A. E., Dunkerton, T. J., Folkins, I., Fu, Q., and Ote, P. W.: Tropical tropopause layer, Rev, Geophys., 47, RG1004, https://doi.org/10.1029/2008RG000267, 2009. 
Fyfe, J. C., Gillett, N. P., and Zwiers, F. W.: Overestimated global warming over the past 20 years, Nat. Clim. Change, 3, 767-769, https://doi.org/10.1038/nclimate1972, 2013.

Fyfe, J. C., Meehl, G. A., England, M. H., Mann, M. E., Santer, B. D., Flato, G. M., Hawkins, E., Gillett, N. P., Xie, S. P., Kosaka, Y., and Swart, N. C.: Making sense of the early2000s warming slowdown, Nat. Clim. Change, 6, 224-228, https://doi.org/10.1038/nclimate2938, 2016.

Gettelman, A., Holton, J. R., and Rosenlof, K. H.: Mass fluxes of $\mathrm{O}_{3}, \mathrm{CH}_{4}, \mathrm{~N}_{2} \mathrm{O}$ and $\mathrm{CF}_{2} \mathrm{Cl}_{2}$ in the lower stratosphere calculated from observational data, J. Geophys. Res., 102, 19149, https://doi.org/10.1029/97JD01014, 1997.

Gettelman, A., Pan, L. L., Randel, W. J., Hoor, P., Birner, T., and Hegglin, M. I.: the Extratropical Upper Troposphere and Lower Stratosphere, Rev. Geophys., 49, 1-31, https://doi.org/10.1029/2011RG000355, 2011.

Hansen, J., Sato, M., Ruedy, R., Nazarenko, L., Lacis, A., Schmidt, G. A., Russell, G., Aleinov, I., Bauer, M., Bauer, S., Bell, N., Cairns, B., Canuto, V., Chandler, M., Cheng, Y., Del Genio, A., Faluvegi, G., Fleming, E., Friend, A., Hall, T., Jackman, C., Kelley, M., Kiang, N., Koch, D., Lean, J., Lerner, J., Lo, K., Menon, S., Miller, R., Minnis, P., Novakov, T., Oinas, V., Perlwitz, J., Perlwitz, J., Rind, D., Romanou, A., Shindell, D., Stone, P., Sun, S., Tausnev, N., Thresher, D., Wielicki, B., Wong, T., Yao, M., and Zhang, S.: Efficacy of climate forcings, J. Geophys. Res.-Atmos., 110, 1-45, https://doi.org/10.1029/2005JD005776, 2005.

Haywood, J. M., Jones, A., Clarisse, L., Bourassa, A., Barnes, J., Telford, P., Bellouin, N., Boucher, O., Agnew, P., Clerbaux, C., Coheur, P., Degenstein, D., and Braesicke, P.: Observations of the eruption of the Sarychev volcano and simulations using the HadGEM2 climate model, J. Geophys. Res.-Atmos., 115, 1-18, https://doi.org/10.1029/2010JD014447, 2010.

Hoerling, M. P., Schaack, T. K., and Lenzen, A. J.: Global Objective Tropopause Analysis, Mon. Weather Rev., 119, 1816-1831, https://doi.org/10.1175/15200493(1991)119<1816:GOTA>2.0.CO;2, 1991.

Hoinka, K. P.: The tropopause: Discovery, definition and demarcation, Meteorol. Z., 6, 281-303, 1997.

Holton, J. R., Haynes, P. H., McIntyre, M. E., Douglass, A. R., Rood, R. B., and Pfister, L.: Stratospheretroposphere exchange, Rev. Geophys., 33, 403-439, https://doi.org/10.1029/95RG02097, 1995.

Hommel, R., Timmreck, C., Giorgetta, M. A., and Graf, H. F.: Quasi-biennial oscillation of the tropical stratospheric aerosol layer, Atmos. Chem. Phys., 15, 5557-5584, https://doi.org/10.5194/acp-15-5557-2015, 2015.

Hoor, P., Fischer, H., Lange, L., Lelieveld, J., and Brunner, D.: Seasonal variations of a mixing layer in the lowermost stratosphere as identified by the $\mathrm{CO}-\mathrm{O}_{3}$ correlation from in situ measurements, J. Geophys. Res.-Atmos., 107, ACL 1-1-ACL 1-11, https://doi.org/10.1029/2000JD000289, 2002.

Hoor, P., Gurk, C., Brunner, D., Hegglin, M. I., Wernli, H., and Fischer, H.: Seasonality and extent of extratropical TST derived from in-situ CO measurements during SPURT, Atmos. Chem. Phys., 4, 1427-1442, https://doi.org/10.5194/acp-4-1427-2004, 2004.

Hostetler, C. A., Liu, Z., Reagan, J., Vaughan, M., Winker, D., Osborn, M., Hunt, W. H., Powell, K. A., and Trepte,
C.: CALIOP Algorithm Theoretical Basis Document - Calibration and Level 1 Data Products, PC-SCI-201 Release 1.0, available at: http://www-calipso.larc.nasa.gov/resources/ pdfs/PC-SCI-201v1.0.pdf (last access: 26 June 2017), 2006.

IPCC: Climate Change 2013: The Physical Science Basis. Contribution of Working Group I to the Fifth Assessment Report of the Intergovernmental Panel on Climate Change, edited by: Stocker, T. F., Qin, D., Plattner, G.-K., Tignor, M., Allen, S. K., Boschung, J., Nauels, A., Xia, Y., Bex, V., and Midgley, P. M., Cambridge University Press, Cambridge, UK and New York, NY, USA, 1535 pp., https://doi.org/10.1017/CBO9781107415324, 2013.

Jäger, H. and Deshler, T.: Lidar backscatter to extinction, mass and area conversions for stratospheric aerosols based on midlatitude balloonborne size distribution measurements, Geophys. Res. Lett., 29, 35-1-35-4, https://doi.org/10.1029/2002GL015609, 2002.

Jäger, H. and Deshler, T.: Erratum: Lidar backscatter to extinction, mass and area conversions for stratospheric aerosols based on midlatitude balloonborne size distribution measurements, Geophys. Res. Lett., 30, 1-4 https://doi.org/10.1029/2003GL017189, 2003.

Jäger, H., Deshler, T., and Hofmann, D. J.: Midlatitude lidar backscatter conversions based on balloonborne aerosol measurements, Geophys. Res. Lett., 22, 1729-1732, https://doi.org/10.1029/95GL01521, 1995.

Kar, J., Vaughan, M. A., Lee, K.-P., Tackett, J. L., Avery, M. A., Garnier, A., Getzewich, B. J., Hunt, W. H., Josset, D., Liu, Z., Lucker, P. L., Magill, B., Omar, A. H., Pelon, J., Rogers, R. R., Toth, T. D., Trepte, C. R., Vernier, J.-P., Winker, D. M., and Young, S. A.: CALIPSO lidar calibration at $532 \mathrm{~nm}$ : version 4 nighttime algorithm, Atmos. Meas. Tech., 11, 1459-1479, https://doi.org/10.5194/amt-11-1459-2018, 2018.

Karl, T. R., Arguez, A., Huang, B., Lawrimore, J. H., McMahon, J. R., Menne, M. J., Peterson, T. C., Vose, R. S., and Zhang, H.-M.: Possible artifacts of data biases in the recent global surface warming hiatus, Science, 348, 1469-1472, https://doi.org/10.1126/science.aaa5632, 2015.

Khaykin, S. M., Godin-Beekmann, S., Keckhut, P., Hauchecorne, A., Jumelet, J., Vernier, J.-P., Bourassa, A., Degenstein, D. A., Rieger, L. A., Bingen, C., Vanhellemont, F., Robert, C., DeLand, M., and Bhartia, P. K.: Variability and evolution of the midlatitude stratospheric aerosol budget from 22 years of ground-based lidar and satellite observations, Atmos. Chem. Phys., 17, 18291845, https://doi.org/10.5194/acp-17-1829-2017, 2017.

Kremser, S., Thomason, L. W., von Hobe, M., Hermann, M., Deshler, T., Timmreck, C., Toohey, M., Stenke, A., Schwarz, J. P., Weigel, R., Fueglistaler, S., Prata, F. J., Vernier, J. P., Schlager, H., Barnes, J. E., Antuña-Marrero, J. C., Fairlie, D., Palm, M., Mahieu, E., Notholt, J., Rex, M., Bingen, C., Vanhellemont, F., Bourassa, A., Plane, J. M. C., Klocke, D., Carn, S. A., Clarisse, L., Trickl, T., Neely, R., James, A. D., Rieger, L., Wilson, J. C., and Meland, B.: Stratospheric aerosol - Observations, processes, and impact on climate, Rev. Geophys., 54, 278-335, https://doi.org/10.1002/2015RG000511, 2016.

Kunz, A., Konopka, P., Müller, R., and Pan, L. L.: Dynamical tropopause based on isentropic potential vorticity gradients, J. Geophys. Res.-Atmos., 116, D01110, https://doi.org/10.1029/2010JD014343, 2011. 
Li, C., Krotkov, N. A., Carn, S., Zhang, Y., Spurr, R. J. D., and Joiner, J.: New-generation NASA Aura Ozone Monitoring Instrument (OMI) volcanic $\mathrm{SO}_{2}$ dataset: algorithm description, initial results, and continuation with the Suomi-NPP Ozone Mapping and Profiler Suite (OMPS), Atmos. Meas. Tech., 10, 445458, https://doi.org/10.5194/amt-10-445-2017, 2017.

Lin, P. and Fu, Q.: Changes in various branches of the Brewer-Dobson circulation from an ensemble of chemistry climate models, J. Geophys. Res.-Atmos., 118, 73-84, https://doi.org/10.1029/2012JD018813, 2013.

Lopez, T., Carn, S., Werner, C., Fee, D., Kelly, P., Doukas, M., Pfeffer, M., Webley, P., Cahill, C., and Schneider, D.: Evaluation of Redoubt Volcano's sulfur dioxide emissions by the Ozone Monitoring Instrument, J. Volcanol. Geoth. Res., 259, 290-307, https://doi.org/10.1016/j.jvolgeores.2012.03.002, 2013.

Martinsson, B. G., Nguyen, H. N., Brenninkmeijer, C. A. M., Zahn, A., Heintzenberg, J., Hermann, M., and van Velthoven, P. F. J.: Characteristics and origin of lowermost stratospheric aerosol at northern midlatitudes under volcanically quiescent conditions based on CARIBIC observations, J. Geophys. Res.-Atmos., 110, 1-12, https://doi.org/10.1029/2004JD005644, 2005.

Martinsson, B. G., Friberg, J., Andersson, S. M., Weigelt, A., Hermann, M., Assmann, D., Voigtländer, J., Brenninkmeijer, C. A. M., van Velthoven, P. J. F., and Zahn, A.: Comparison between CARIBIC Aerosol Samples Analysed by AcceleratorBased Methods and Optical Particle Counter Measurements, Atmos. Meas. Tech., 7, 2581-2596, https://doi.org/10.5194/amt-72581-2014, 2014.

Martinsson, B. G., Friberg, J., Sandvik, O. S., Hermann, M., van Velthoven, P. F. J., and Zahn, A.: Particulate sulfur in the upper troposphere and lowermost stratosphere - sources and climate forcing, Atmos. Chem. Phys., 17, 10937-10953, https://doi.org/10.5194/acp-17-10937-2017, 2017.

McCormick, M. P., Thomason, L. W., and Trepte, C. R.: Atmospheric effects of the Mt Pinatubo eruption, Nature, 373, 399404, https://doi.org/10.1038/373399a0, 1995.

Medhaug, I., Stolpe, M. B., Fischer, E. M., and Knutti, R.: Reconciling controversies about the "global warming hiatus", Nature, 545, 41-47, https://doi.org/10.1038/nature22315, 2017.

Meehl, G. A. and Teng, H.: CMIP5 multi-model hindcasts for the mid-1970s shift and early 2000s hiatus and predictions for 2016-2035, Geophys. Res. Lett., 41, 1711-1716, https://doi.org/10.1002/2014GL059256, 2014.

Murphy, D. M., Froyd, K. D., Schwarz, J. P., and Wilson, J. C.: Observations of the chemical composition of stratospheric aerosol particles, Q. J. Roy. Meteor. Soc., 140, 1269-1278, https://doi.org/10.1002/qj.2213, 2014.

Myhre, G., Shindell, D., Bréon, F.-M., Collins, W., Fuglestvedt, J., Huang, J., Koch, D., Lamarque, J.-F., Lee, D., Mendoza, B., Nakajima, T., Robock, A., Stephens, G., Takemura, T., and Zhang, H.: Anthropogenic and Natural Radiative Forcing, in: Climate Change 2013: The Physical Science Basis. Contribution of Working Group I to the Fifth Assessment Report of the Intergovernmental Panel on Climate Change, edited by: Stocker, T. F., Qin, D., Plattner, G.-K., Tignor, M., Allen, S. K., Boschung, J., Nauels, A., Xia, Y., Bex, V., and Midgley, P. M., Cambridge University Press, Cambridge, UK and New York, NY, USA, 2013.

Pan, L. L. and Munchak, L. A.: Relationship of cloud top to the tropopause and jet structure from
CALIPSO data, J. Geophys. Res.-Atmos., 116, D12201, https://doi.org/10.1029/2010JD015462, 2011.

Pardini, F., Burton, M., Arzilli, F., La Spina, G., and Polacci, M.: Satellite-derived $\mathrm{SO}_{2}$ flux time-series and magmatic processes during the 2015 Calbuco eruptions, Solid Earth Discuss., https://doi.org/10.5194/se-2017-64, 2017.

Prata, A. J. and Bernardo, C.: Retrieval of volcanic $\mathrm{SO}_{2}$ column abundance from Atmospheric Infrared Sounder data, J. Geophys. Res.-Atmos., 112, 1-17, https://doi.org/10.1029/2006JD007955, 2007.

Prata, A. T., Young, S. A., Siems, S. T., and Manton, M. J.: Lidar ratios of stratospheric volcanic ash and sulfate aerosols retrieved from CALIOP measurements, Atmos. Chem. Phys., 17, 85998618, https://doi.org/10.5194/acp-17-8599-2017, 2017.

Rajaratnam, B., Romano, J., Tsiang, M., and Diffenbaugh, N. S.: Debunking the climate hiatus, Climatic Change, 133, 129-140, https://doi.org/10.1007/s10584-015-1495-y, 2015.

Ridley, D. A., Solomon, S., Barnes, J. E., Burlakov, V. D., Deshler, T., Dolgii, S. I., Herber, A. B., Nagai, T., Neely, R. R., Nevzorov, A. V., Ritter, C., Sakai, T., Santer, B. D., Sato, M., Schmidt, A., Uchino, O., and Vernier, J. P.: Total volcanic stratospheric aerosol optical depths and implications for global climate change, Geophys. Res. Lett., 41, 7763-7769, https://doi.org/10.1002/2014GL061541, 2014.

Rieger, L. A., Bourassa, A. E., and Degenstein, D. A.: Merging the OSIRIS and SAGE II stratospheric aerosol records, J. Geophys. Res., 120, 8890-8904, https://doi.org/10.1002/2015JD023133, 2015.

Robock, A.: Volcanic eruptions and climate, Rev. Geophys., 38, 191-219, https://doi.org/10.1029/1998RG000054, 2000.

Rollins, A. W., Thornberry, T. D., Watts, L. A., Yu, P., Rosenlof, K. H., Mills, M., Baumann, E., Giorgetta, F. R., Bui, T. V., Höpfner, M., Walker, K. A., Boone, C., Bernath, P. F., Colarco, P. R., Newman, P. A., Fahey, D. W., and Gao, R. S.: The role of sulfur dioxide in stratospheric aerosol formation evaluated by using in situ measurements in the tropical lower stratosphere, Geophys. Res. Lett., 44, 4280-4286, https://doi.org/10.1002/2017GL072754, 2017.

Sakai, T., Uchino, O., Nagai, T., Liley, B., Morino, I., and Fujimoto, T.: Long-term variation of stratospheric aerosols observed with lidars over Tsukuba, Japan, from 1982 and Lauder, New Zealand, from 1992 to 2015, J. Geophys. Res., 121, 1028310293, https://doi.org/10.1002/2016JD025132, 2016.

Santer, B. D., Bonfils, C., Painter, J. F., Zelinka, M. D., Mears, C., Solomon, S., Schmidt, G. A., Fyfe, J. C., Cole, J. N. S., Nazarenko, L., Taylor, K. E., and Wentz, F. J.: Volcanic contribution to decadal changes in tropospheric temperature, Nat. Geosci., 7, 185-189, https://doi.org/10.1038/ngeo2098, 2014.

Sato, M., Hansen, J. E., McCormick, M. P., and Pollack, J. B.: Stratospheric aerosol optical depths, 1850-1990, J. Geophys. Res., 98, 22987, https://doi.org/10.1029/93JD02553, 1993.

Sheng, J. X., Weisenstein, D. K., Luo, B. P., Rozanov, E., Stenke, A., Anet, J., Bingemer, H., and Peter, T.: Global atmospheric sulfur budget under volcanically quiescent conditions: Aerosolchemistry-climate model predictions and validation, J. Geophys. Res., 120, 256-276, https://doi.org/10.1002/2014JD021985, 2015.

Solomon, S., Daniel, J. S., Neely, R. R., Vernier, J.-P., Dutton, E. G., and Thomason, L. W.: The Persistently Variable "Background" 
Stratospheric Aerosol Layer and Global Climate Change, Science, 333, 866-870, https://doi.org/10.1126/science.1206027, 2011.

Surono, Jousset, P., Pallister, J., Boichu, M., Buongiorno, M. F., Budisantoso, A., Costa, F., Andreastuti, S., Prata, F., Schneider, D., Clarisse, L., Humaida, H., Sumarti, S., Bignami, C., Griswold, J., Carn, S., Oppenheimer, C., and Lavigne, F.: The 2010 explosive eruption of Java's Merapi volcano-A "100-year" event, J. Volcanol. Geoth. Res., 241-242, 121-135, https://doi.org/10.1016/j.jvolgeores.2012.06.018, 2012.

Thomas, H. E., Watson, I. M., Carn, S. A., Prata, A. J., and Realmuto, V. J.: A comparison of AIRS, MODIS and OMI sulphur dioxide retrievals in volcanic clouds, Geomatics, Nat. Hazards Risk, 2, 217-232, https://doi.org/10.1080/19475705.2011.564212, 2011.

Thomason, L. W., Ernest, N., Millán, L., Rieger, L., Bourassa, A., Vernier, J.-P., Manney, G., Luo, B., Arfeuille, F., and Peter, T.: A global space-based stratospheric aerosol climatology: 1979-2016, Earth Syst. Sci. Data, 10, 469-492, https://doi.org/10.5194/essd-10-469-2018, 2018.

Trenberth, K. E.: Has there been a hiatus?, Science, 349, 691-692, https://doi.org/10.1126/science.aac9225, 2015.

Vernier, J. P., Pommereau, J. P., Garnier, A., Pelon, J., Larsen, N., Nielsen, J., Christensen, T., Cairo, F., Thomason, L. W., Leblanc, T., and McDermid, I. S.: Tropical Stratospheric aerosol layer from CALIPSO Lidar observations, J. Geophys. Res.-Atmos., 114, 1-12, https://doi.org/10.1029/2009JD011946, 2009.

Vernier, J. P., Thomason, L. W., Pommereau, J. P., Bourassa, A., Pelon, J., Garnier, A., Hauchecorne, A., Blanot, L., Trepte, C., Degenstein, D., and Vargas, F.: Major influence of tropical volcanic eruptions on the stratospheric aerosol layer during the last decade, Geophys. Res. Lett., 38, 1-8, https://doi.org/10.1029/2011GL047563, 2011.

Wilcox, L. J., Hoskins, B. J., and Shine, K. P.: A global blended tropopause based on ERA data. Part I: Climatology, Q. J. Roy. Meteor. Soc., 138, 561-575, https://doi.org/10.1002/qj.951, 2012.
Winker, D. M., Hunt, W. H., and McGill, M. J.: Initial performance assessment of CALIOP, Geophys. Res. Lett., 34, 1-5, https://doi.org/10.1029/2007GL030135, 2007.

Winker, D. M., Vaughan, M. A., Omar, A., Hu, Y., Powell, K. A., Liu, Z., Hunt, W. H., and Young, S. A.: Overview of the CALIPSO mission and CALIOP data processing algorithms, J. Atmos. Ocean. Tech., 26, 2310-2323, https://doi.org/10.1175/2009JTECHA1281.1, 2009.

Winker, D. M., Pelon, J., Coakley, J. A., Ackerman, S. A., Charlson, R. J., Colarco, P. R., Flamant, P., Fu, Q., Hoff, R. M., Kittaka, C., Kubar, T. L., Le Treut, H., McCormick, M. P., Mégie, G., Poole, L., Powell, K., Trepte, K., Vaughan, M. A., and Wielicki, B. A.: The Calipso Mission: A Global 3D View of Aerosols and Clouds, B. Am. Meteorol. Soc., 91, 1211-1229, https://doi.org/10.1175/2010BAMS3009.1, 2010.

Xie, S. P., Kosaka, Y., and Okumura, Y. M.: Distinct energy budgets for anthropogenic and natural changes during global warming hiatus, Nat. Geosci., 9, 29-33, https://doi.org/10.1038/ngeo2581, 2016.

Yan, X. H., Boyer, T., Trenberth, K., Karl, T. R., Xie, S. P., Nieves, V., Tung, K. K., and Roemmich, D.: The global warming hiatus: Slowdown or redistribution?, Earth's Futur., 4, 472-482, https://doi.org/10.1002/2016EF000417, 2016.

Young, S. A., Winker, D. M., Noel, V., VaughanOmar, A., Hu, Y., and Kuehn, R. E.: CALIOP algorithm theoretical basis document, Part 5: Extinction Retrieval and Particle Property Algorithms, Theor. Basis Doc., June, PC-SCI-203 Part 5, available at: http://www-calipso.larc.nasa.gov (last access: 20 June 2017), 2005.

Zuev, V. V., Burlakov, V. D., Nevzorov, A. V., Pravdin, V. L., Savelieva, E. S., and Gerasimov, V. V.: 30-year lidar observations of the stratospheric aerosol layer state over Tomsk (Western Siberia, Russia), Atmos. Chem. Phys., 17, 3067-3081, https://doi.org/10.5194/acp-17-3067-2017, 2017. 